\title{
The Role of Gamma Delta T Cells in Autoimmune Rheumatic Diseases
}

\section{Ilan Bank}

Rheumatology Unit, Autoimmunity Center, Sheba Medical Center, Tel-Hashomer 52621, Israel; ibank@tauex.tau.ac.il

Received: 15 January 2020; Accepted: 15 February 2020; Published: 18 February 2020

\begin{abstract}
Autoimmune rheumatic diseases (ARDs), affecting 1-1.5\% of all humans, are associated with considerable life long morbidity and early mortality. Early studies in the 1990s showed numerical changes of the recently discovered $\gamma \delta \mathrm{T}$ cells in the peripheral blood and in affected tissues of patients with a variety of ARDs, kindling interest in their role in the immuno-pathogenesis of these chronic inflammatory conditions. Indeed, later studies applied rapid developments in the understanding of $\gamma \delta \mathrm{T}$ cell biology, including antigens recognized by $\gamma \delta \mathrm{T}$ cells, their developmental programs, states of activation, and cytokine production profiles, to analyze their contribution to the pathological immune response in these disorders. Here we review the published studies addressing the role of $\gamma \delta$ $\mathrm{T}$ in the major autoimmune rheumatic diseases, including rheumatoid arthritis, juvenile idiopathic arthritis, ankylosing spondylitis, systemic lupus erythematosus and scleroderma, and animal models thereof. Due to their unique properties spanning adaptive and innate immune functions, the ever deeper understanding of this unique $\mathrm{T}$ cell population is shedding new light on the pathogenesis of, while potentially enabling new therapeutic approaches to, these diseases.
\end{abstract}

Keywords: gammadelta $\mathrm{T}$ cells; rheumatoid arthritis; systemic lupus erythematosus; systemic sclerosis; ankylosing spondylitis; juvenile idiopathic arthritis

\section{Introduction}

In the mid 1980s, the previously elusive nature of the T cell receptor (TCR) expressed by CD4 ${ }^{+}$ and $\mathrm{CD}^{+}$major histocompatibility complex (MHC) restricted $\mathrm{T}$ cells had just been established to be encoded by rearranging $\alpha$ and $\beta$ TCR gene [1,2]. However, the serendipitous discovery of a third rearranging gene, termed $\gamma$, in a murine clone of cytotoxic $\alpha \beta$ T cells, confounded by absent expression of a protein encoded by this gene, raised questions relating to the role of this newcomer [3]. These were resolved in 1986, when two papers revealed human thymocyte derived CD4 ${ }^{-} \mathrm{CD} 8^{-} \mathrm{T}$ cell clones and peripheral blood T cell clones expressing a second TCR composed of two polypeptide chains associated with the CD3 molecule, one of which was encoded by the "mysterious" $\gamma$ gene, and the second later shown to be encoded by a fourth TCR gene, $\delta$ [4-6].

Since those early years, $\gamma \delta$ T cells have been shown to be prototypes of "unconventional" $\mathrm{T}$ cells. Their unconventionality, is exemplified by the opportunity they present for broadening the "universe" of antigens that can be recognized by T cells. Thus, as opposed to MHC restricted CD4 ${ }^{+}$ and $\mathrm{CD}^{+} \alpha \beta$ T cells, $\gamma \delta$ TCR do not recognize peptide antigens within classical MHC molecules. Rather, their $\mathrm{T}$ cell receptors mediate direct recognition of non peptidic molecules currently known to include cell surface expressed butyrophilins (whose recognition and stimulatory properties are enhanced by intracellular low molecular weight phospho-antigens), phycoerythrine, glycosides, t-RNA synthetase, and other intracellular enzymes, heat shock proteins, the non-classical MHC like molecules CD1, MR1, and endothelial protein C receptor (EPCR) [7]. Furthermore, different subsets of $\gamma \delta \mathrm{T}$ cells distinguished by the $\mathrm{V}$ genes used in their TCR may have evolved to recognize different antigens and 
presenting molecules. For example, human $\gamma \delta$ TCR that use the $\mathrm{V} \gamma 9$ and $\mathrm{V} \delta 2$ genes $\left(\mathrm{V} \gamma 9 \mathrm{~V} \delta 2^{+} \gamma \delta\right.$ $\mathrm{T}$ cells) recognize butyrophilin $3 \mathrm{~A} 1$ to which a phosphoantigen has bound intracellularly on target cells [8]. By contrast, other butyrophilins, as well as CD1d, may serve as antigenic targets of the second major subset of human $\gamma \delta \mathrm{T}$ cells, namely those using the $\mathrm{V} \delta 1$ gene $[9,10]$. This unusual antigenic repertoire however, is only now beginning to be unraveled, and is likely to be greatly expanded and detailed in the future. In addition, $\gamma \delta \mathrm{T}$ cells follow unique intra- and extra-thymic pathways of functional maturation [11,12]. Thus, for example, imprinting of subsets of $\gamma \delta \mathrm{T}$ cells resulting in an innate ability to produce the potent proinflammatory interleukin (IL)-17, in the absence of TCR activation, takes place during thymic maturation [13]. This contrasts with the requirement for antigenic encounters in peripheral lymph nodes, in order for conventional naïve $\alpha \beta$ T cells to acquire effector functions. An additional distinguishing feature is the affinity of certain subsets of $\gamma \delta \mathrm{T}$ cells, to establish residence, directly after exit from the thymus, in specific peripheral tissues, most prominently along mucosal and dermal epithelial surfaces [12]. Furthermore, the specific tissue is dictated by V genes of the $\gamma \delta$ TCR [12]. These features, together with other broad functional properties overlapping those of innate and adaptive immune cells i.e., secretion of a wide spectrum of cytokines potential including tumor necrosis factor (TNF) $\alpha$ type I and II cytokines, to mediate potent cytotoxicity, help for $\mathrm{B}$ cells, immune regulatory potential, and even regulation of tissue metabolism, positions these cells to serve a unique and non redundant role within the immune system and has been the subject of recent excellent reviews, highly recommended to the reader $[11,12,14]$. Furthermore, $\gamma \delta \mathrm{T}$ cells were shown to undergone major perturbations in the context of infectious, autoimmune, and malignant diseases [15].

In the context of disease conditions, interest of the scientific community has primarily focused on $\gamma \delta$ $\mathrm{T}$ cells in cancer, encompassing their contradictory ability to either control or enhance malignancy [16]. Only $\sim 100$ published studies have studied $\gamma \delta \mathrm{T}$ cells in the context of autoimmune rheumatic disorders, which represent a significant health burden affecting 1-1.5\% of the global human population with considerable morbidity, and in some diseases increased [17]. In this comprehensive review, we summarize research from publications found in PubMed in which the major autoimmune rheumatic disorders (ARDs) (rheumatoid arthritis (RA), juvenile idiopathic arthritis (JIA), systemic lupus erythematosus (SLE), ankylosing spondylitis (AS) and systemic sclerosis (SSc)) were addressed with reference to $\gamma \delta \mathrm{T}$ cells. Experimental animal models representing these diseases, in which the contribution of $\gamma \delta \mathrm{T}$ cells was studied, are also described. When considered in total, it appears that $\gamma \delta \mathrm{T}$ cells play an important and unique role in these diseases. Furthermore, given the increasing understanding of the underlying principles governing $\gamma \delta \mathrm{T}$ cell recognition and physiology, these and future studies are contributing to a wider comprehension of the pathogenesis of ARDs, and may point to new ways of treating these devastating conditions.

\section{Rheumatoid Arthritis}

\subsection{Numerical Alterations of $\gamma \delta T$ Cells in $R A$}

In an early study, a decrease of CD4-CD8- (mostly $\gamma \delta \mathrm{T}$ cells) in peripheral blood (PB) of RA patients relative to healthy controls (HC) was noted $(1.38 \pm 1.08 \%$ vs. $3.23 \pm 2.12 \%, p<0.05]$, whereas these cells were increased in synovial fluid (SF) of patients [18]. Similarly, a decrease in PB in both RA and psoriatic arthritis (PsA) patients relative to HC was found in a different cohort [19]. However, in another study, although RA in young ( $40.9 \pm 7.5$ years) was associated with higher levels of PB $\gamma \delta$ $\mathrm{T}$ cells than in old $(76.1 \pm 4.9$ years) patients, their percentage was not different from age matched controls [20]. Likewise, while increased $\gamma \delta \mathrm{T}$ cells were noted in the lamina propria in the intestinal mucosa (mean $5.5 \%$, range $2-12 \%$ ) in rheumatoid factor (RF) positive patients $(n=8)$ compared with RF negative RA patients and a disease control group $(n=15$, mean $2 \%$, range $0.5-5 \% ; p<0.01)$ similar changes were not detectable in PB [21]. In yet another study, the percentages (mean $\pm \mathrm{SEM}=6.3 \pm$ $0.8 \%, n=22)$ and absolute numbers $(70 \pm 11$ /microliters, $n=22)$ of $\gamma \delta \mathrm{T}$ cells in PB from RA patients were not different from those of 22 age-matched HC (7.5 $\pm 0.9 \%, 81 \pm 17 /$ microliters, respectively) [22]. 
Interestingly however, among a cohort of 24 RA patients, $\gamma \delta$ T-cell levels were likewise not significantly different between controls, $4.46 \pm 1.36 \%$, gold salt treated (GST, $6.88 \pm 1.73 \%$ ), and total RA patients $(2.73 \pm 0.55 \%)$, but $42 \%$ of the GST treated group had $\gamma \delta$ T-cell levels higher than the entire untreated RA group [20]. Finally, as opposed to these studies predominantly showing either unaltered or decreased levels of $\gamma \delta \mathrm{T}$ cells in the PB of RA patients, a single study reported 10 patients with RA in whom $\gamma \delta \mathrm{T}$ cells were $5.5 \% \pm 4.38$ (mean \pm s.d.), which was significantly increased as compared with 22 healthy subjects $(2.09 \pm 1.01, p<0.001)$ [23].

With respect to subsets of $\gamma \delta \mathrm{T}$ cells, one study reported that in early RA ( $>6$ months $(\mathrm{m})<8 \mathrm{~m}$ disease duration) the percentage of $\mathrm{V} \gamma 9 \mathrm{~V} \delta 2^{+} \mathrm{T}$ cells in the $\mathrm{PB}$ was the same as controls. Their percentage in synovium, however was higher than in PB of patients and controls. These cells also expressed high levels of human leukocyte antigen (HLA)-DR and CD86 [24]. Concurring with this, the total percentage of $\mathrm{V} \gamma 9 \mathrm{~V} \delta 2 \mathrm{~T}$ cells was the same as controls among another group of early RA patients, most of whom were anti citrulline peptide antibody (ACPA) positive. However, among these, there was an increase of $\mathrm{V} \gamma 9 \mathrm{~V} \delta 2 \mathrm{~T}$ cells bearing a terminal effector memory CD27 ${ }^{-} \mathrm{CD} 45 \mathrm{RA}^{+}$phenotype (TEMRA) and a decrease of naïve $\mathrm{CD} 27^{+} \mathrm{CD} 45 \mathrm{RA}^{+}$cells [25]. Contrasting with these results, among 19 adults with early active $\mathrm{RA}, 80 \%$ of whom were $\mathrm{RF}^{+}$or anti-cyclic citrullinated peptide (CCP) ${ }^{+}$and on no current steroid treatment, $\mathrm{V} \gamma 9 \mathrm{~V} \delta 2 \mathrm{~T}$ cells and regulatory $\mathrm{T}$ cells (Tregs) were lower, whereas the total percent of $\gamma \delta \mathrm{T}$ cells was same as in HC [26]. Likewise, among 68 patients with RA (not necessarily designated as early RA), 21 with osteoarthritis (OA) and $21 \mathrm{HC}$, the percent of $\gamma \delta \mathrm{T}$ cells in $\mathrm{PB}$ was found to be significantly lower in the RA patients, and the percent of $\mathrm{V} \delta 2^{+} \mathrm{T}$ cells in PB was also decreased in RA relative to OA and $\mathrm{HC}$. By contrast, in SF and synovial tissue $\mathrm{V} \delta 2^{+} \mathrm{T}$ cells were increased ( $5.9 \%$ vs. $1.2 \%)$. Interestingly, anti tumor necrosis factor (TNF) $\alpha$ treatment was associated with increased levels of $\mathrm{V} \delta 2^{+}$cells in the periphery [27]. Similarly, Lamour found that the total $\gamma \delta$ $\mathrm{T}$ cell percentage decreased relative to $\mathrm{HC}$, and that the $\mathrm{V} \delta 2^{+}$subset was decreased relative to the $\mathrm{V} \delta 1^{+}$subset. Furthermore, human leukocyte antigen (HLA)-DR increased during active disease on $\gamma \delta \mathrm{T}$ cells of RA patients [28]. Thus, in RA, the PB $\gamma \delta \mathrm{T}$ cell subset expressing the common $\mathrm{V} \gamma 9$ and $\mathrm{V} \delta 2$ combination in the TCR $(\mathrm{V} \gamma 9 \mathrm{~V} \delta 2 \mathrm{~T}$ cells), appears to be unchanged or decreased-in particular in advanced phases of the disease-and bears stigmata of having been activated during the disease process. Furthermore, since PB may be relatively depleted of $\mathrm{V} \gamma 9 \mathrm{~V} \delta 2 \mathrm{~T}$ cells, whereas synovial $\mathrm{V} \gamma 9 \mathrm{~V} \delta 2$ $\mathrm{T}$ cells are relatively expanded in synovium relative to $\mathrm{PB}$, transmigration of this subset to the site of inflammation appears to be one mechanism of accumulation of $\gamma \delta$ T cell in the rheumatoid synovium.

In contrast to the findings in most of these studies, showing normal or decreased percentages of $\gamma \delta \mathrm{T}$ cells in the PB of RA patients, large expansions of these cells can be found in patients with RA and large granular lymphocyte (LGL) proliferation of $\gamma \delta \mathrm{T}$ cells. Thus, in one study, $3.6 \%$ of patients with RA had $>10 \%$ LGL $\left(\mathrm{CD}^{+} \mathrm{CD}^{+} 6^{+}\right)$in the PB. These patients were not clinically distinct, other than developing cytopenias, but significantly more were under anti TNF $\alpha$ therapy and $\sim 60 \%$ of the LGL expansions were $\gamma \delta \mathrm{T}$ cell clones [29]. Furthermore, among 14 patients with $\gamma \delta \mathrm{T}$ cell-LGL leukemia, (11 men and three women), six had a history of RA. Eight of 12 patients had a CD4 ${ }^{-} \mathrm{CD} 8^{-}$phenotype, and 4 had a $C D 4^{-} \mathrm{CD}^{+}$phenotype. In this study, patients with $\gamma \delta \mathrm{T}$-LGL leukemia were more likely to have RA than those with other forms of LGL leukemia $(p=0.04)$ and median overall survival for the six patients with RA was 209 months, compared to 62 months for eight patients without RA ( $p=0.7$ ) [30]. In another study, however, while $20 \%$ of patients with $\gamma \delta$ LGL had RA (4/20), a similar proportion of 169 patients with $\alpha \beta$ LGL also developed RA [31].

\section{2. $\gamma \delta T$ Cells in Rheumatoid Synovium}

Whereas synovia from patients with OA, SLE and joint trauma did not show an increased presence of $\gamma \delta \mathrm{T}$ cells, these cells were increased in a subset of RA patients. RA patients with $\gamma \delta \mathrm{T}$ cell infiltrates in the synovium had an increased tissue inflammation score compared to RA synovia with few $\gamma \delta$ T cells [18.6 \pm 5.8 versus $11.6 \pm 4.2, p<0.05$ ] [32]. In another study, among 23 rheumatoid synovial membranes, using immunohistology and monoclonal antibodies (mAb), the majority showed only 
limited staining for $\delta$-chain antibodies, with 20 of the 23 tissues appearing to have less than $1 \%$ of $\mathrm{T}$ lymphocytes expressing $\delta$ chains. Nevertheless, three tissues stained extensively for both $\delta$ (all $\gamma \delta \mathrm{T}$ cells) and $\delta \mathrm{TCS} 1\left(\mathrm{~V} \delta 1^{+}\right)$in particular areas of the section. In these areas, small perivascular lymphocytic aggregates appeared to be composed mainly of $\gamma \delta \mathrm{T}$ cells [33]. In addition, the expression of CD16 was reduced, and HLA-DR increased in synovial $\gamma \delta$ T cells in RA patients [34]. These findings indicate that $\gamma \delta \mathrm{T}$ cells participate in the inflammatory process occurring in the synovium in RA and express an activated phenotype.

\subsection{TCR Gene Expression}

A study of synovial membrane lymphocytes from the RA patients, which confirmed a selective expansion of $\gamma \delta \mathrm{T}$ cells $(8.8 \%$ in synovial membrane versus $4 \%$ in $\mathrm{PB})$ also found, by immunohistochemical studies, that the TCR of the $\gamma \delta \mathrm{T}$ cells was unusual inasmuch as most $\gamma \delta \mathrm{T}$ cells did not express $\mathrm{V} \delta$ or $\mathrm{V} \delta$ genes, that predominate in PB [35]. Further analysis of synovial $\mathrm{T}$ cells, using a $\mathrm{mAb}$ (B18) specific for $\mathrm{V} \gamma 8$ revealed, indeed, that in PB of healthy persons, only 6 $\pm 5 \%$ and only 1 of $35 \gamma \delta \mathrm{T}$ cell clones were $\mathrm{V} \gamma 8^{+}$, whereas the $\mathrm{B} 18^{+}$subset was a dominant $\gamma \delta \mathrm{T}$ cell population among intraepithelial lymphocytes (IEL) derived from the human intestine $(74 \pm$ $29 \%, p<0.002)$, and in the SF of patients with RA ( $21 \pm 18 \%, p<0.05$ compared with normal PB). Furthermore, the B18 $8^{+}$subset was more frequent among IL-2-expanded $\gamma \delta \mathrm{T}$ cells $(42 \pm 20 \%)$ derived from synovial tissue than among IL-2-expanded cells derived from HC PB $(p<0.002)$ and PB from RA patients $(p<0.02)$. All B18 ${ }^{+}$clones $(n=7)$ expressed mRNA for $\mathrm{V} \gamma 8$ together with mRNA for $\mathrm{V} \delta 1$ $(n=5)$ or mRNA for $\mathrm{V} \delta 3(n=2)$. Thus, $\gamma \delta \mathrm{T}$ cells expressing $\mathrm{V} \gamma 8$, together with mainly $\mathrm{V} \delta 1$, form a major $\gamma \delta \mathrm{T}$ cell subset among the IEL of the gut and a highly frequent subset in the synovial tissue of patients with RA [36]. In another study, reverse transcriptase-polymerase chain reaction (RT-PCR), in conjunction with nucleotide sequencing, revealed a frequent usage of the $\mathrm{V} \gamma 3$ gene segment in RA synovial fluid mononuclear cells (SFMC) which was rare in PBMC of healthy individuals, where the $V \gamma 9$ gene predominated. The $V \gamma 3$ gene in RA SFMC showed no conserved junctional sequence and $\mathrm{V} \gamma 3$ expressing clones were non-reactive to mycobacterium tuberculosis, as opposed to the $\mathrm{V} \gamma 9^{+}$ clones [37]. Others, using PCR to amplify TcR $\gamma$ - and $\delta$-chain transcripts, found SFMC expressing TCR $\gamma$-chain transcripts which used the same set of $\mathrm{V} \gamma$ genes as peripheral blood mononuclear cells (PBMC). The majority of patients expressed a restricted SMC V $\delta$-chain repertoire biased towards V $\delta 1$. V $\delta 2$ mRNA transcripts were also detected, albeit at low levels, in some patients [38]. Interestingly, the level of expression of the $4 \mathrm{~V} \gamma$ gene family members was determined by PCR, and 509 cDNA clones were derived from $8 \mathrm{SF}$ and one PB sample from 2 patients with RA and one patient with JIA, subcloned and sequenced. Disproportionate expression of a subpopulation of TCR $\gamma$ mRNA transcripts were found in each patient and some of these transcripts were expressed by $\mathrm{T}$ cells found in both joints, consistent with a common antigen driven response in the joints [39]. In addition, in contrast to control PBMC, V 81 chain cDNA derived from PBMC of three patients showed a strong bias towards usage of the same $\mathrm{V}$-joining $(\mathrm{J})$ combination and junctional region sequences, although the specific sequences were unique in each patient, whereas oligoclonality of the V $\delta 1$ chain was less marked in SFMC of two of these patients and absent in SFMC of the other patients. For V $\delta 2$, oligoclonality was detected in PBMC of two patients. In SFMC of a single patient, a dominant V $\delta 2$ transcript was detected that utilized the $\mathrm{J} \delta 2$ segment, which was rarely expressed in the normal TCR repertoire. These results indicate in vivo clonal expansion of V $\delta 1$ - and V $\delta 2$-expressing $\gamma \delta \mathrm{T}$ cells in the PB of RA patients contrasting with a synovial T cell infiltrate which consists largely of polyclonally expanded $\gamma \delta \mathrm{T}$ cells, but showing clonal dominance in some patients [40]. Moreover, it appears that $\gamma \delta \mathrm{T}$ cells may expand in RA synovium to consist a unique population characteristically enriched in $\mathrm{V} \delta 1^{+} \mathrm{T}$ cells and often co-expressing $\mathrm{V} \gamma 8$ and $\mathrm{V} \gamma 3$ genes, which suggests they recognize MR1 [41]. In summary, the synovium in RA contains $\gamma \delta$ $\mathrm{T}$ cells with a polyclonal repertoire, although sometimes containing oligoclonal expansions common to different joints. Synovial $\mathrm{V} \gamma 9 \mathrm{~V} \delta 2^{+} \mathrm{T}$ cells, which consist of the predominant phenotype in healthy $\mathrm{PB}$, may be expanded in synovium relative to the patient's $\mathrm{PB}$, but usually form a less prominent 
component of the synovial $\gamma \delta \mathrm{T}$ cell infiltrate. The infiltrate may include less common types of $\gamma \delta \mathrm{T}$ cells, but is usually enriched for $\mathrm{V} \delta 1^{+} \mathrm{T}$ cells that use unusual $\mathrm{V} \gamma$ genes, some of which have been associated with reactivity with non classical MHC like molecules. Together, these findings suggest that synovial $\gamma \delta$ T cells may be selected by specific antigens found in the synovium.

\subsection{Functions of $\gamma \delta T$ Cells in $R A$}

$\mathrm{V} \gamma 9 \mathrm{~V} \delta 2 \mathrm{~T}$ cells isolated from patients with early RA were found to be capable of presenting peptide antigens to $\mathrm{CD} 4^{+} \mathrm{T}$ cells. In support of this, they expressed high levels of HLA-DR and CD86, molecules involved in antigen presentation, and characteristic of antigen presenting cells [24]. In addition, IFN $\gamma(\sim 50 \%), \mathrm{TNF} \alpha(\sim 40 \%)$, and IL-17 $(\sim 3.7 \%)$ were demonstrated to be produced by the indicated percentages of RA synovial $V \gamma 9^{+} \mathrm{T}$ cells. Furthermore, RA SF V $\delta 2^{+} \mathrm{T}$ cells expressed high levels of C-X-C motif chemokine receptor (CXCR) 3 and C-C motif chemokine receptor (CCR) 5 that were upregulated by TNF $\alpha$ in a nuclear factor (NF)-kb dependent pathway, and migrated to RA SF more efficiently than HC and OA derived cells. V $\delta \gamma \delta \mathrm{T}$ cells, however, had lower levels of the chemokine receptors [27]. In another study, among $22 \gamma \delta \mathrm{T}$ cell clones obtained from the SF and PB of one patient with inflammatory arthritis (and compared to $26 \alpha \beta \mathrm{TCR}^{+} \mathrm{T}$ cell clones of the same and different patients), IFN $\gamma$ was produced by $82 \%$ and IL- 4 by $77 \%$ of the $22 \gamma \delta$ T cell clones whereas IL-10 was not. The mean levels of IL-4 were lower for clones derived from SF. Thus, the most common pattern was a $\gamma \delta$ Th1-like pattern, primarily found in SF derived $\mathrm{V} \delta 1^{+}$clones. A $\gamma \delta$ Th0-like pattern (balanced production of both IFN $\gamma$ and IL-4), a $\gamma \delta$ Th1 pattern (IFN $\gamma$ alone) and a $\gamma \delta$ Th2 pattern (IL-4 alone) were also found. These three patterns were also seen in PB V $\delta 2^{+} \gamma \delta \mathrm{T}$ cells. However, $\gamma \delta \mathrm{T}$ cell clones produced lower levels of IFN $\gamma(p=0.001)$ and higher levels of IL-4 than $\alpha \beta$ T cell clones $(p<$ 0.02) [42]. In addition, in one patient with RA, LGL $\gamma \delta$ cells, that expressed a V $\gamma 9^{-} \mathrm{V} \delta 2^{+}$phenotype, and constituted $60 \%$ of the PB T cells, did not proliferate, but did secrete TNF $\alpha$ when triggered with anti-CD3, and the addition of these cells to decreased their secretion of immunoglobulin (Ig) $\mathrm{M}$ from pokeweed mitogen-stimulated B cells from the patient, while augmenting IgG secretion [43]. In contrast to these potential pro-inflammatory and immunogenic functions, $\mathrm{CD}^{+}$Th17 cells but not $\gamma \delta \mathrm{T}$ cells, were found in apposition to tartrate-resistant acid phosphatase positive osteoclasts in subchondral areas of inflamed joints in mice with collagen induced arthritis (CIA), and this pattern was reproduced in synovial biopsies of patients with RA [44]. Thus, $\gamma \delta$ T cells of RA patients exhibit functional properties including antigen presentation, help for antibody production and predominantly TH1 like cytokine profiles, but may play a less significant role in bone resorption during the inflammatory process.

\subsection{Responses to Putative Antigen}

In a pioneering study, clones from rheumatoid synovium expressing $\mathrm{V} \gamma 9 \delta 2$ were shown to respond to synthetic alkyl phosphates and particularly to monoethyl phosphate (MEP) [45]. Later on, $\gamma \delta$ T cells from synovial fluid were also shown to be reactive to isopentenyl pyrophosphate (IPP), an important endogenously produced phosphoantigen and an additive effect of a low dose of ethanol increased IPP induced proliferation of synovial $\gamma \delta \mathrm{T}$ cells, with similar findings applying to normal PB $\gamma \delta \mathrm{T}$ cells [46]. Other antigens for RA derived $\gamma \delta \mathrm{T}$ cells have been reported sporadically. Thus, among $15 \mathrm{~T}$ cell clones reactive with aggrecan, (a proteoglycan that binds to glycosaminoglycan hyaluronan through its amino terminal, the G1 globular domain), that were derived from PB of RA patients, 2 were $\gamma \delta \mathrm{TCR}^{+}$[47]. In addition, six human $\mathrm{V} \delta 1^{+} \mathrm{T}$ cell lines were derived from RA SF, and were shown to selectively lyse Daudi, but not K562 cells in an MHC-unrestricted manner which was inhibited by anti-CD3 mAb. Since cold target inhibition assays showed that cytotoxicity was competitively inhibited by autologous and allogeneic primarily cultured RA synovial cells as well as synovial sarcoma and chondrosarcoma lines whereas PB did not inhibit this cytotoxicity, the authors concluded that $\mathrm{V} \delta 1^{+} \mathrm{T}$ cells in rheumatoid synovial may recognize an antigen which is commonly expressed on cells derived from RA synovium [48]. A further antigenic reactivity was suggested by the proliferative response of mononuclear cells (MC) in SF and PB of patients with to mycobacterial $65 \mathrm{kDa}$ heat shock protein 
(HSP65). Higher response of SFMC than PBMC to HSP65 was noted in 14 of 19 patients with RA, and stimulation indexes of RA-SFMC correlated significantly with HLA-DR ${ }^{+} \gamma \delta^{+} \mathrm{T}$ cell percentage suggesting reactivity of SFMC $\gamma \delta \mathrm{T}$ cells with HSP65 [49]. Finally, in one study, RA-derived V $\gamma 9 \mathrm{~V} \delta 2 \mathrm{~T}$ cell clones, appeared to display dual antigenic recognition: a nonclonal, MHC-unrestricted recognition of mycobacteria, and a clonal recognition of a short tetanus toxin peptide presented by HLA-DRw53, a nonpolymorphic class II MHC molecule associated with susceptibility to rheumatoid arthritis. This was the first evidence for dual antigenic recognition by $\gamma \delta \mathrm{T}$ cells and suggested that $\mathrm{V} \gamma 9 \mathrm{~V} \delta 2 \mathrm{~T}$ cells could recognize nominal antigenic peptides presented by class II MHC molecules [50]. Taken together, these reports support the idea that $\mathrm{V} \delta 1^{+} \gamma \delta \mathrm{T}$ cells in the synovium may be responding to local antigens expressed on synoviocytes, whereas the $\mathrm{V} \gamma 9 \mathrm{~V} \delta 2 \mathrm{~T}$ cells that enter the joint in response to inflammatory stimuli, participate locally by recognizing phosphoantigens presented by butyrophilins expressed in the synovium (Figure 1).

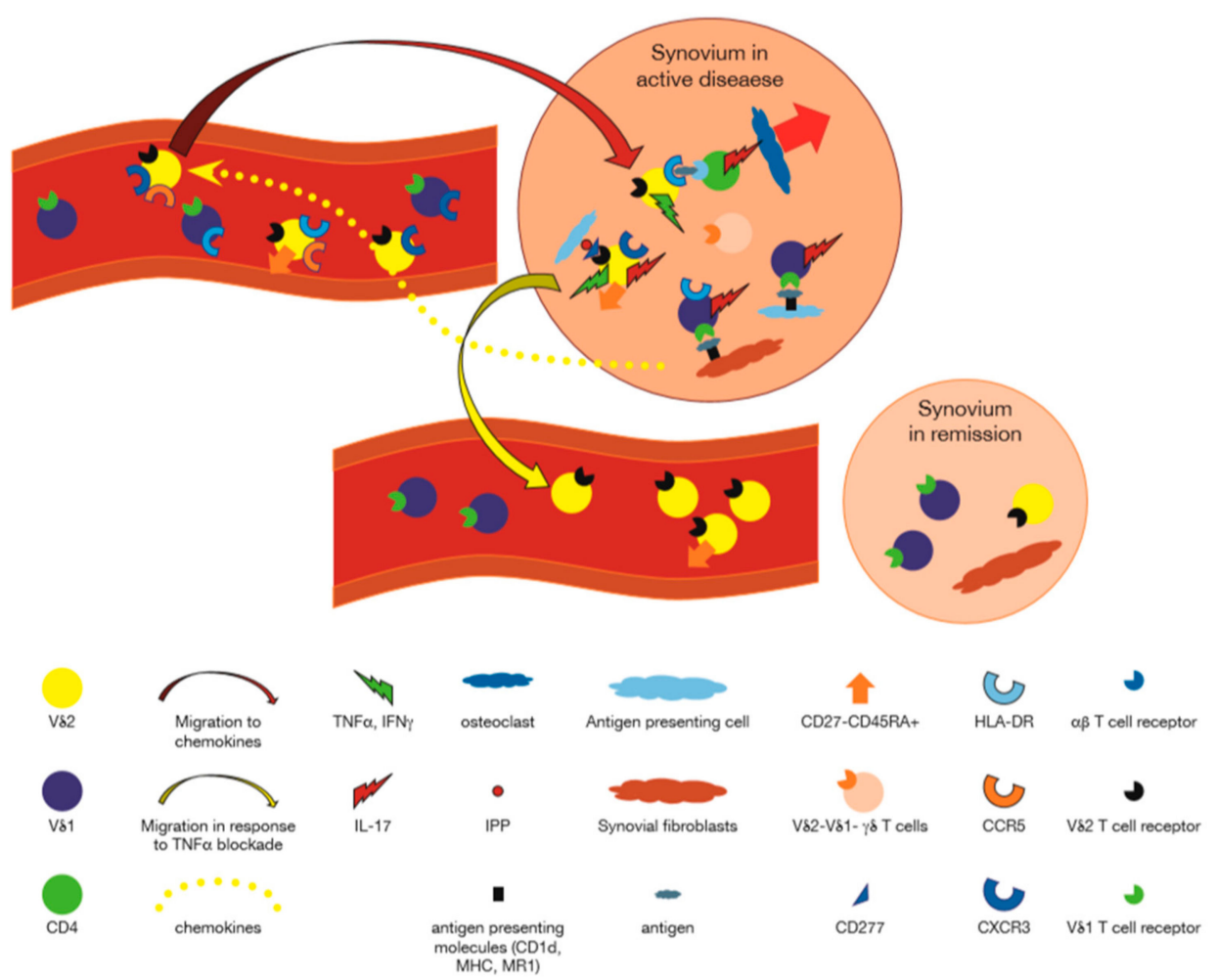

Figure 1. Participation of $\gamma \delta \mathrm{T}$ cells in Rheumatoid Arthritis. $\mathrm{V} \delta 1^{+} \gamma \delta \mathrm{T}$ cells using $\mathrm{V} \gamma 3, \mathrm{~V} \gamma 8$ or other $\mathrm{V} \gamma$ genes, recognize antigens presented by CD1d or MR1 on synovial fibroblasts, and/or antigens presented by antigen presenting cells, and secrete cytokines such as interleukin (IL)-17, IL-4, and IFN $\gamma[27,37,38,40,41,48]$. Chemokines produced in inflamed synovium, attract C-X-C motif chemokine receptor (CXCR) 5 and C-C motif chemokine receptor (CCR)3 expressing $\mathrm{V} \gamma 9^{+} \mathrm{T}$ cells to the synovium [27]. These cells are activated by phosphoantigens presented by CD277 expressing cells in the synovium to express human leukocyte antigen (HLA)-DR, and in turn, may present antigens to $\mathrm{CD} 4^{+} \alpha \beta$ T cells [24]. $\mathrm{V} \delta 1^{-} \mathrm{V} \delta 2^{-} \gamma \delta \mathrm{T}$ cells recognizing unknown antigens also participate in the synovial reaction [35]. IL-17 secreted by $\mathrm{CD}^{+} \alpha \beta \mathrm{T}$ cells activated by $\mathrm{V} \gamma 9^{+} \gamma \delta \mathrm{T}$ cells may attract neutrophils and lead to osteoclastogenesis. In the presence of anti tumor necrosis factor (TNF) $\alpha$ antibodies, chemokines retaining the $\mathrm{V} \gamma 9^{+} \mathrm{T}$ cells are decreased, and these cells migrate out of the joint to the peripheral blood. Peripheral blood $\gamma \delta$ T cells express activation markers acquired in lymph nodes or as a reflection of activation in the synovium [24,25,28]. 


\subsection{Relationship to Disease Activity and Severity}

Among 50 RA patients, $\gamma \delta$ T cells in PB significantly decreased in negative correlation with the value of $\mathrm{C}$-reactive protein (CRP), a marker of systemic inflammation, although they had no correlation with the titer of RF [22]. Furthermore, in patients with RA-associated neutropenia and expansions of LGL $\gamma \delta \mathrm{T}$ cells in the $\mathrm{PB}$, absence of $\mathrm{V} \delta 2^{+} \mathrm{T}$ cells along with prominent $\mathrm{V} \delta 1^{+} \mathrm{T}$ cells in $\mathrm{PB}$ was associated with longstanding severe disease whereas patients with proliferation of $\mathrm{V} \delta 2$ cells had less severe disease, suggesting an association of the composition of the peripheral $\gamma \delta \mathrm{T}$ cell repertoire and disease severity [51]. In this regard, it was further shown that among 19 adults with early active RA, $80 \%$ of whom were $\mathrm{RF}^{+}$or $\mathrm{CCP}^{+}$and on no current steroid treatment, treatment with 99Tc-methylene diphosphonate (99Tc-MDP) increased $\mathrm{V} \gamma 9 \delta 2$ cells and Tregs (which were lower before treatment). Disease activity score (DAS)28, that evaluates disease activity in RA, decreased, as did concentrations of serum TNF $\alpha$, IL-10, IL-6 during treatment with 99Tc-MDP, whereas IFN $\gamma$ was unchanged and TGF $\beta$ increased [26]. Similarly, among sixty-eight patients with RA, \% of V $22 \mathrm{~T}$ cells in PB correlated inversely with erythrocyte sedimentation rate (ESR), CRP, and DAS28 [27]. In another study, it was shown that among early RA patients of whom 8/10 were $\mathrm{ACPA}^{+}$, there was an increase of $\mathrm{V} \gamma \delta^{+} \mathrm{CD} 27-\mathrm{CD} 45 \mathrm{RA}^{+}$ TEMRA cells, which correlated with DAS28. These cells produced high levels of IL-6, 8, and IFN $\gamma$ ex-vivo, as well as in vitro, after stimulation with phorbol myristate acetate (PMA) and ionomycin. Furthermore, the number of cytokine producing cells correlated with DAS28 [25]. In all, it appears that the levels of $\gamma \delta \mathrm{T}$ cells, in particular that of the $\mathrm{V} \gamma 9 \mathrm{~V} \delta 2^{+}$subset correlates with disease activity, decreasing with active disease while acquiring a TEMRA phenotype, and increasing during remission after treatment. A summary of how $\gamma \delta \mathrm{T}$ cells participate in the immune process of RA based on the data described in the preceding paragraphs, is presented in Table 1 and in graphic form in Figure 1.

\section{Rodent Models of Rheumatoid Arthritis}

\subsection{Rat Models}

In Mycobacterium tuberculosis-induced rat adjuvant arthritis (AA), protocols to deplete of TCR $\gamma \delta$ (bright) cells in PB and lymph nodes, did not influence clinical parameters. If rats were treated before the clinical peak of adjuvant arthritis, however, joint destruction was significantly more severe than in vehicle-treated rats. The critical time window of intervention seemed to be limited to the span between the onset and the clinical peak of synovitis, since only anti $\gamma \delta$ TCR treatment given in this phase, and not protocols administered before induction or around the peak of the disease, aggravated the degree of joint destruction [52]. In another study of AA in rats mediated by T lymphocytes specific for Mycobacterium tuberculosis, T cells bearing the $\alpha \beta$ TCR were depleted from circulation by treatment with a mAb against the rat $\alpha \beta$ TCR which efficiently suppressed existing disease. By contrast, there was no evidence that $\gamma \delta \mathrm{T}$ cells contributed to AA induction [53]. Likewise, in oil-induced arthritis, a genetically restricted polyarthritis that develops in the DA rats after injection of the mineral oil Freund's incomplete adjuvant, disease was suppressed by $\mathrm{CD} 8^{+} \mathrm{T}$ cells but not by depletion of $\gamma \delta \mathrm{T}$ cells with a mAb (mAb) [54]. Finally, in the model of intradermal injection of squalene, a role for genes within the major histocompatibility complex, was concluded from comparative studies of MHC congenic rat strains. Treatment with anti $\alpha \beta$ TCR but not anti $\gamma \delta$ TCR prevented disease [55]. In conclusion of these studies, it appeared that in these models of rat arthritis, $\gamma \delta \mathrm{T}$ cells may play a role if any, during the effector rather than induction phases of the disease.

\subsection{Murine Model}

In collagen induce arthritis (CIA) —induced by injections of collagen II in complete Freund adjuvant (CFA) with mycobacterium butyricum - in B10.Q male and DBA/1 female mice, CIA was no different in TCR $\delta^{-/-}$mice than in controls, but was, in contrast, abrogated in TCR $\beta^{-/-}$mice. The authors concluded that $\alpha \beta$ T cells are necessary for CIA development and for an IgG response towards CII, whereas $\gamma \delta$ T cells are neither necessary nor sufficient for development of CIA [56]. In another study, 
moreover, a mAb to TCR $\gamma \delta$ had no effect, and actually slightly worsened arthritis, despite the fact that $\gamma \delta \mathrm{T}$ cells consisted up to $35 \%$ of the total T cells in the joints of mice with CIA. Some $\gamma \delta \mathrm{T}$ cells using $\mathrm{V} \gamma 1,-2,-4$, and -6 and $V \delta 1,-2,-5$, and -7 were found in the joints of normal mice, and this repertoire was similar to that found in arthritis joints [57]. These results therefore recapitulated those found in rat arthritis as detailed above.

However, when the individual responses of the two mains peripheral $\gamma \delta \mathrm{T}$ cell subsets, $\mathrm{V} \gamma 1^{+}$and $\mathrm{V} \gamma 4^{+}$cells, during CIA was examined, a more complex scenario unfolded. Thus, whereas both subsets increased in number, only the $\mathrm{V} \gamma 4^{+}$cells became activated during CIA. These $\mathrm{V} \gamma 4^{+}$cells appeared to be antigen (Ag)-selected, based on preferential $\mathrm{V} \gamma 4 / \mathrm{V} \delta 4$ pairing and very limited TCR junctions. Furthermore, in both the draining lymph node and the joints, the vast majority of the $\mathrm{V} \gamma 4 / \mathrm{V} \delta 4^{+}$cells produced IL-17, a key cytokine in the development of CIA. In fact, the number of IL-17-producing $\mathrm{V} \gamma 4^{+} \gamma \delta \mathrm{T}$ cells in the draining lymph nodes was found to be equivalent to the number of $\mathrm{CD}^{+} \alpha \beta \mathrm{TCR}$ Th-17 cells. When mice were depleted of $\mathrm{V} \gamma 4^{+}$cells, clinical disease scores were significantly reduced and the incidence of disease was lowered. A decrease in total IgG and IgG2a anti-collagen antibodies (Abs) was also seen. These results suggested that $\mathrm{V} \gamma 4 \mathrm{~V} \delta 4^{+} \gamma \delta \mathrm{T}$ cells exacerbate CIA through their production of IL-17 [58].

Further support for the role of $\gamma \delta$ T cells in antigen induced arthritis, was obtained in a model wherein methylated Bovine Serum Albumin (mBSA, $8 \mathrm{mg} / \mathrm{mL}$ ) was emulsified in an equal volume of CFA containing heat-killed $M$. tuberculosis. At day 7, mice were immunized intradermally with mBSA/CFA and a week later, mBSA was injected intra-articularly to induce mono-arthritis. Inflammation in the joint was associated with high levels of IL-17 producing $\gamma \delta \mathrm{T}$ cells, and the expression of retinoic acid receptor related orphan receptor gamma (ROR $\gamma$ )t was dependent upon IL-23 suggesting that IL-23 regulates IL-17A and ROR $\gamma \mathrm{t}$ expression in $\gamma \delta \mathrm{T}$ cells in arthritis [59]. Furthermore, in both CIA and as well as in samples from patients with RA, an inhibitor of ROR $\gamma$ T suppressed IL-17 production in $\gamma \delta$ T cells stimulated with IL1 $\beta$ and IL23 ${ }^{+}$IPP [60]. Further mechanistic research came from a study to understand the role of IFN-lambda1 (IL-29), the main cytokine of class II cytokines (including IL-10 and IFN $\alpha \beta$ ) in humans. This cytokine is not expressed in mice, where IL-28A/B instead, plays the major role. In the setting of CIA in male DBA/1OlaHsd mice and IL28-/- mice, therapeutic administration of IL-28A decreased IL-1 $\beta$, IL23, and Th17 and $\gamma \delta$ T cells producing IL-17 in the draining lymph nodes but not in PB. The target of IL-28 was neutrophils, due to their expression of IL-28R, suggesting a neutrophil mediated mechanism for $\gamma \delta$ T cell involvement in CIA [61]. Another model studied the role of ES-62, a phosphorylcholine (PC)-containing glycoprotein secreted by the filarial nematode Acanthocheilonema viteae that acts to modulate the host immune response in order to promote the establishment of chronic helminth infection. ES-62 selectively induced toll like receptor (TLR) $4^{+} \gamma \delta$ T cells with the capacity to produce IL-22 but not IL-17 during CIA [62]. In addition, ES-62 down-regulated IL-17 responses in mice with CIA by targeting a complex IL-17-producing network, involving signaling between dendritic cells and $\gamma \delta$ or $\mathrm{CD}^{+} \mathrm{T}$ cells. Thus, although it did not inhibit IL-17 produced by direct activation with IL-1/IL-23, ES-62 modulated the migration of $\gamma \delta$ T cells by direct suppression of CD44 up-regulation and, as evidenced by in situ analysis, dramatically reduced levels of IL-17-producing cells, including lymphocytes, infiltrating the joint [63]. In yet another model, IL-10 receptor dominant-negative transgenic ( $\mathrm{Tg}$ ) and control mice were immunized with bovine type II collagen to induce arthritis. Blocking IL-10 signaling in T cells rendered mice highly susceptible to CIA. The suppressive function of $\mathrm{CD}^{+}{ }^{+} \mathrm{Foxp}^{+}$regulatory $\mathrm{T}$ cells was significantly impaired in $\mathrm{Tg}$ mice because of the reduced ability of Tregs from $\mathrm{Tg}$ mice to maintain their levels of Foxp3. The higher level of IL-17 mRNA detected in inflammatory joints of $\mathrm{Tg}$ mice, was attributed to the recruitment of $\mathrm{IL}-17^{+} \gamma \delta \mathrm{T}$ cells into the arthritic joints since IL-10 deficiency did not affect the percent of CD4 ${ }^{+}$IL-17producing cells in the joint [64].

$\gamma \delta \mathrm{T}$ cells were found to be the predominant population among IL-17-producing cells in the swollen joints of mice with CIA, and the absolute numbers of these cells increased in parallel with disease activity. However, IL-17-producing $\gamma \delta$ T cells expressed chemokine receptor 6 were maintained by IL-23 but 
not by type II collagen in vitro, and were induced antigen independently in vivo. Furthermore, IL-17 production by $\gamma \delta$ T cells was induced by IL-1 $\beta$ plus IL-23 independently of TCR triggering. However, in autoimmune arthritis in SKG mice which is induced using zymosan as an adjuvant, in contrast to what was observed in mice with CIA, IL-17-producing $\gamma \delta \mathrm{T}$ cells were nearly absent in the affected joints. In this study, it was noted in addition, that in joints of patients with RA, IL-17-producing $\gamma \delta \mathrm{T}$ cells were rarely observed, whereas Th1 cells were predominant [65]. Likewise, as previously noted, it has been found that in CIA, CD4 ${ }^{+}$Th17, and IL-17 producing $\gamma \delta$ T cells in the joints of arthritic mice similarly induced osteoclastogenesis in vitro. However, individual depletion and adoptive transfer studies revealed that in vivo, Th17 cells dominated with regard to bone destruction. Thus, unlike $\gamma \delta \mathrm{T}$ cells, Th17 cells were found in apposition to tartrate-resistant acid phosphatase positive osteoclasts in subchondral areas of inflamed joints, a pattern reproduced in patient biopsies [44].

Taken together, while clearly demonstrating involvement of $\gamma \delta \mathrm{T}$ cells in experimental arthritis, these data highlight the need to dissect subsets of $\gamma \delta \mathrm{T}$ cells when analyzing their role in pathogenesis of antigen induced arthritis in mice, while supporting the idea that their role is not directly associated with a direct response to the instigating antigen, but rather is related to effector mechanisms such as IL-23 induced production of IL-17 at the site of inflammation.

Indeed, several models support the idea that in classical antigen induced arthritis, $\gamma \delta \mathrm{T}$ cells play an effector role downstream of and independent of direct antigen recognition. For example, it was demonstrated that, in the induction phase of CIA, CD4 ${ }^{+} \mathrm{Th} 17$ cells in the lamina propria are activated. In $\mathrm{CD} 4{ }^{+} \mathrm{Cre} \mathrm{ROR} \gamma$ floxed mice arthritis was mitigated, despite continued production of IL-17 by $\gamma \delta$ T cells [66]. By contrast, in arthritis that does not require any antigen to induce disease, but rather is induced by injected gene transfer of IL-23 in B10.RIII mice, $\gamma \delta \mathrm{T}$ cell depletion with $\mathrm{mAb}$ decreased neutrophils in joints and spleen while increasing IL-27 production by neutrophils and activated macrophages, resulting in abrogation of the arthritis. Blocking with anti TCR $\gamma \delta \mathrm{mAb}$ also resulted in reduced IL-17 but not TNF $\alpha$, interferon (IFN) $\gamma$ or interleukin (IL)-6. Thus, in this non antigen requiring form of arthritis, $\gamma \delta$ T cells played a major role. It was further shown that IL-27 itself inhibited $\gamma \delta$ T cells and reduced IL-23 induced arthritis [67]. In addition, IL-1 receptor(R) antagonist (a)-deficient $\left(111 \mathrm{rn}^{--}\right)$mice spontaneously develop arthritis in an IL-17- and T-cell dependent manner suggesting that excess IL-1 signaling caused by IL-1Ra deficiency induces IL-17 production from T cells and the development of arthritis. IL-1R and IL-23R expressing $V \gamma 6^{+} \gamma \delta$ IL 17 cells expressing high levels of C-C chemokine receptor (CCR2) type 2 are the main producers of IL-17 in joints of Il1rn ${ }^{--}$mice. Importantly, without $\mathrm{CD} 4$ cells, no arthritis occurred, and the $\mathrm{CD} 4^{+} \mathrm{T}$ cells were responsible for inducing C-C motif chemokine ligand (CCL) 2 in the joints, that attracted the pathogenic $\gamma \delta \mathrm{T}$ cells [68]. Interestingly, in yet another model it was shown that pathogenic $\gamma \delta \mathrm{T}$ cells may be under the control of other subsets of T cells. Thus, mice were given Salmonella enterica serovar Enteritidis \#5694 by gavage. BALB/C J $\alpha 18-/-$ mice KO mice and anti CD1d treated mice developed more severe intestinal inflammation and worse arthritis. Infected mice had a higher percentage of IL-17 producing $\gamma \delta \mathrm{T}$ cells and depletion with anti $\gamma \delta$ TCR partially abrogated joint inflammation. Mice treated with $\alpha$ galcer to activate induced natural killer (iNKT) T cells had less IL-17 $\gamma \delta$ T cells and less arthritis but an increase of Th17 cells suggesting the pivotal role of IL-17 producing $\gamma \delta$ T cells in this model [69]. Finally, a single intraperitoneal injection of mannan from the yeast S. cerevisiae into B10Q. Ncf1m1j/m1j (reactive oxygen species (ROS) deficient) mice resulted in a worse arthritis and psoriasis than that developing in wildtype B10Q mice. Arthritis was mediated by IL-17, and in this model the source of the cytokine was $\gamma \delta$ and not $\alpha \beta$ T cells. The secretion of IL-17 was dependent on TNF $\alpha$ produced by macrophages. It was thought that TLR2 expression by macrophages and $\gamma \delta$ T cells might be responsible for the effect of mannan, revealing a mechanism for activation of pathogenic $\gamma \delta \mathrm{T}$ cells independent of a nominal antigen [70].

The main findings of these experimental models are summarized in Table 2. The cumulative data suggest that specific subsets of $\gamma \delta \mathrm{T}$ cells play an important role in the inflammatory response in the joint space in models of arthritis, primarily by secreting IL-17. Furthermore, this response appears to be independent of the inciting protein auto-antigen (e.g., collagen) used to induce disease. Thus, it appears 
that $\gamma \delta \mathrm{T}$ cell responses in arthritis are dependent, upon non TCR driven mechanisms, including cytokines (IL-1, IL-23, and IL-28) and chemokines affecting homing to the synovium, although a specific contribution of certain antigen selected $\gamma \delta \mathrm{T}$ cells (e.g., $\mathrm{V} \gamma 4 \mathrm{~V} \delta 4^{+} \mathrm{T}$ cells) may also play a role.

\section{Juvenile Idiopathic Arthritis}

\subsection{Numerical Evaluation and Relationship to Disease Activity}

$\mathrm{CD}^{-}{ }^{-} \mathrm{CD} 8^{-}$double negative $(\mathrm{DN})$ and $\gamma \delta \mathrm{T}$ cell levels were measured in 42 patients with active JIA and in $10 \mathrm{HCs}$ who were comparable for age by an immunofluorescence double staining procedure. All 3 JIA onset types had DN and $\gamma \delta$ T cell levels not significantly different from those of controls. No correlation was found between DN or $\gamma \delta$ T cell levels and ESR values or the number of active joints. When patients were divided according to treatment, $\mathrm{DN}$ and $\gamma \delta \mathrm{T}$ cell levels were significantly lower ( $p=0.001, p=0.02$, respectively) in patients receiving methotrexate (MTX) than in patients not receiving MTX [71]. However, in another study of JIA, $80 \%$ of CD4-CD8- of T cells were $\gamma \delta$ T cells and $\gamma \delta$ cells secreting IL-17 were positively correlated with innate lymphoid cells (ILC) type 3 secreting IL-17, which in turn correlated with disease severity by physician visual analogue score (VAS) [72]. In another study, when analyzed in relation to subsets of JIA, an elevated percentage of $\gamma \delta \mathrm{T}$ cells in PB was found in quiescent systemic JIA which decreased in active disease [73].

In studies of $\gamma \delta \mathrm{T}$ cells in the SF, it was found that in oligoarticular JIA, SF contained higher Treg (10.01\% vs. $2.66 \%$ of $\left.\mathrm{CD}^{+} \mathrm{CD}^{+}\right)$and $\gamma \delta \mathrm{T}$ cells $(20.29 \%$ vs. $10.58 \%$ of CD3) than PB, and that higher levels of $\gamma \delta$ T cells $919 \%$ vs. 15\%) predicted more relapse within a median of 35.6 months [74]. Moreover, in another study of the SF of children with JRA, there were significantly more V $\delta 1^{+} \mathrm{CD} 69^{+}$ and $\mathrm{V} \delta 2^{+} \mathrm{CD} 69^{+}$cells compared with the PB of the same patients. The majority of the $\mathrm{V} \delta 1^{+}$cells expressed the high molecular weight isoform $\left(\mathrm{CD} 45 \mathrm{RA}^{+}\right)$while most of the $\mathrm{V} \delta 2^{+}$cells carried the low molecular weight variant $\left(\mathrm{CD}_{4} \mathrm{RO}^{+}\right)$of this molecule [75]. In addition, when samples of PB $(n=$ $25)$ and SF $(n=93)$ were analyzed by flow cytometry in $93 \mathrm{JIA}$ patients, $\mathrm{V} \delta 1^{+}$and $\mathrm{V} \gamma 9^{+} \gamma \delta \mathrm{T}$ cell subsets were detected in SF of all patients. However, only the percentage of $\mathrm{V} \delta 1^{+}$cells was higher in SF compared to PB $(p<0.01)$. Interestingly, although the distribution of $\gamma \delta \mathrm{T}$ cell subsets was similar in different JIA subgroups, antinuclear antibody (ANA)-positive patients had a higher percentage of SF V $\delta 1^{+} \mathrm{T}$ cells than ANA-negative patients $(p<0.01)$. The percentage of SF $\mathrm{V}^{+} 1^{+} \mathrm{T}$ cells was inversely associated with age at onset, recurrence of synovitis, and ESR; and that of SF V $\gamma 9^{+} \mathrm{T}$ cells was inversely correlated with age at onset and was higher in patients who recovered from disease $(n=15)$. IPP-induced expansion of SF $V \gamma 9^{+} \mathrm{T}$ cells correlated with disease remission, whereas the expansion of SF $V \gamma 9^{+}$T cells in media with IL-2 alone was significantly greater in patients with uveitis [76]. Taken together, these reports suggest a critical role for $\gamma \delta$ T cells and their subsets in JIA, which may fluctuate with disease subtypes.

\subsection{Functional Characteristics}

In addition to IL-6 and IL-18, IL-17A was prevalent in sera from patients with active systemic JIA, while ex vivo (inactive disease) and in vitro experiments revealed that $\gamma \delta \mathrm{T}$ cells overexpressed this cytokine. This was not seen with $\mathrm{CD}^{+} \mathrm{T}$ cells, which expressed strikingly low levels of IFN $\gamma$. Therapeutic IL-1 blockade was associated with partial normalization of cytokine expression phenotypes. Culturing healthy donor $\gamma \delta$ T cells in serum from systemic JIA patients or in medium spiked with IL-1 $\beta$, IL-18, and S100A12 induced IL-17 overexpression at levels similar to those observed in the patients' cells and anti IL-1 blocked the increase [77]. Another study of JIA with or without enthesitis revealed an increase of $\gamma \delta$ T cells in JIA patients (9.3 $\pm 4.6 \%$ vs. $5.12 \pm 2.61 \%)$ associated with an increase of $\mathrm{IL} 7^{+} \gamma \delta^{+}$and decrease of IFN $\gamma^{+} \gamma \delta$ cells relative to controls [19]. Finally, among JIA patients, SF V $\gamma 9^{+}$ T cells, expressed higher CD69 than those in PB. Moreover, only SF V $\gamma 9^{+} \mathrm{T}$ cells were further activated by contact with synovial fibroblasts to express more CD69 and secrete TNF $\alpha$ and these functions were augmented by zoledronate, which also augmented IFN $\gamma$ by SF $V \gamma 9^{+} \mathrm{T}$ cells to a greater degree than 
PB V $\gamma 9^{+} \mathrm{T}$ cells. Proliferation of these cells was suppressed by contact with synovial fluid regulatory $\mathrm{T}$ cells. Furthermore, cell-cell contact with the V $\gamma 9 \mathrm{~T}$ cells induced synovial fibroblast apoptosis [78]. Together these results suggest complex pathogenic as well as possible protective roles for subsets of $\gamma \delta$ $\mathrm{T}$ cells in JIA.

\section{Murine Models Relevant to JIA}

To study a model of systemic JIA, wild-type (WT) and IFN $\gamma$-knockout (KO) BALB/c mice were challenged with CFA, and clinical symptoms and biologic characteristics analyzed. In WT mice, CFA injection resulted in splenomegaly, lymphadenopathy, neutrophilia, thrombocytosis, and increased cytokine expression. In the absence of IFN $\gamma$, arthritis, anemia, hemophagocytosis, abundance of immature blood cells, and increased levels of IL-6, all of which are reminiscent of the symptoms of systemic JIA, were noted. CFA-challenged IFN-KO mice showed increased expression of IL-17 by CD4 $\mathrm{T}$ cells and by innate $\gamma \delta \mathrm{T}$ cells. Inflammatory and hematologic changes were prevented by treatment with $\mathrm{mAb}$ to IL-12/IL-23p40 and by anti IL-17 antibodies, indicating a role of IL-17- producing $\gamma \delta \mathrm{T}$ cells in this syndrome [79]

\section{Ankylosing Spondylitis (AS)}

In a pioneering study, IL-23 receptor (IL-23R) expression in T cells was determined in 17 active AS, 8 patients with PsA, 9 patients with RA and $20 \mathrm{HC}$. The proportion of IL-23R-expressing T cells in the periphery was 2-fold higher in AS patients than in $\mathrm{HC}$, and this was specifically driven by a 3-fold increase in IL-23R ${ }^{+} \gamma \delta \mathrm{T}$ cells in AS patients. Increased IL23R expression on $\gamma \delta \mathrm{T}$ cells was also associated with enhanced IL-17 secretion, with no observable IL-17 production from IL-23R- $\gamma \delta$ T cells in AS patients. Furthermore, $\gamma \delta$ T cells from AS patients were heavily skewed toward IL-17 production in response to stimulation with IL-23 and/or anti-CD3/CD28. In PsA patients, IL23R ${ }^{+} \gamma \delta \mathrm{T}$ cells were also higher but they were not IL-17 secretors. Interestingly, IL23R ${ }^{+} \gamma \delta \mathrm{T}$ cells were also found in joints of patients with crystal induced arthritis [80]. In another study, ROR $\gamma \mathrm{t}^{+}$Tbetlo PLZF- iNKT and $\gamma \delta$ TCR “high" T cell subsets were found in healthy PB and in AS patients. ROR $\gamma \mathrm{t}^{+}$iNKT and $\gamma \delta-h i \mathrm{~T}$ cells showed IL-23 mediated Th17-like immune responses and were clearly enriched within inflamed joints of spondyloarthritis patients, where they acted as major IL-17 secretors. The ROR $\gamma \mathrm{t} \gamma \delta \mathrm{TCR}$ high cells were mainly $\mathrm{V}^{+}$, expressed IL-23R mRNA, and responded to IL-23 by producing IL-17 and IL-22. The frequency of $\gamma \delta$ TCR "high" cells and also of IL23R ${ }^{+} \gamma \delta$ T cells was higher in SF than in PB, cells. ROR $\gamma \mathrm{t}$ inhibition selectively targeted IL-17 producing iNKT and $\gamma \delta$-T cells enriched in spondyloarthritis patients [81]. In addition, IL-17 and granulocyte monocyte colony stimulating factor (GM-CSF) double producing $\gamma \delta \mathrm{T}$ cells were found to be increased in PB of AS patients when compared to RA patients and normal PB, similar to what was found with respect to CD4, CD8 and natural-killer (NK) cells [82]. Another study confirmed that double expressing IL-17 and GMCSF $\gamma \delta$ as well as CD4, CD8, and ILC cells are found in synovium and increased in PB of AS patients, whereas there was a decreased percent of $\gamma \delta \mathrm{T}$ cells in their PB relative to normal [83]. Interestingly, in contrast to IL23R ${ }^{+}$ $\mathrm{IL}-17^{+} \mathrm{V} \delta 1^{+} \mathrm{T}$ cells that are expanded in AS, $\mathrm{V} \delta 2^{+} \gamma \delta \mathrm{T}$ cells were found to be increased in patients with AS who were receiving infliximab (anti TNF $\alpha$ ) therapy, relative to those not receiving this drug and HC. Most of these V $\delta 2^{+}$T cells secreted IFN $\gamma$ and not IL-17 [84].

A single study addressed antigenic reactivities in AS. Four randomly derived synovial $\mathrm{V} \gamma 9^{+}$ $\gamma \delta-\mathrm{TCR}^{+}$clones from SF of patients with spondyloarthropathy killed both autologous and allogeneic target cells when infected with live Yersinia or Salmonella and also uninfected Daudi cells expressing GroEL heat shock protein. One clone was specific for Yersinia-infected targets. Three $\gamma \delta$-TCR ${ }^{+}$ clones were cytotoxic when uninfected autologous or allogeneic targets were employed. Polymorphic "classical" MHC class I or class II molecules were not used as restriction elements for cytotoxicity [85]. Taken together, the results of these studies support a unique and critical role of IL-17 secreting, IL-23 responsive $\mathrm{V} \delta 1^{+} \gamma \delta \mathrm{T}$ cells in the pathogenesis of AS. 


\section{Murine Model Relevant to Ankylosing Spondylitis}

In a pivotal study, $\gamma \delta \mathrm{T}$ cells were found to be abundant in uninflamed entheseal tissue and constituted the large majority of ROR $\gamma \mathrm{t}^{+} \mathrm{IL}^{-23 \mathrm{R}^{+}}$enthesis resident lymphocytes. These cells were generated from fetal thymus dependent $\mathrm{V} \gamma 6^{+} \mathrm{CD} 44^{+} \mathrm{CD}_{2} 7^{-} \gamma \delta \mathrm{T}$ cells and were the main source of IL-17A at the enthesis. Under inflammatory conditions supplied by introduction of the IL-23 gene, $\gamma \delta$ T cells increased in number at the Achilles tendon enthesis, aortic root, and adjacent to the ciliary body, consisting $25 \%$ relative to $1 \%$ in the lymph node and $40 \%$ of the $\mathrm{V} \gamma 6^{+}$cells secreted IL-17 [86].

\section{Systemic Lupus Erythematosus}

\subsection{In Vivo Levels of $\gamma \delta T$ Cells and Their Correlation with Disease Activity}

In a study of 21 patients with SLE and 17 healthy donors, $\gamma \delta \mathrm{T}$ cells were significantly decreased whereas the frequencies of HLA-DR ${ }^{+} \gamma \delta \mathrm{T}$ cells and $\mathrm{CD} 9^{+} \gamma \delta \mathrm{T}$ cells were significantly higher in patients $\left(p<0.001\right.$ and $p<0.05$ respectively) compared with HC. CD94 ${ }^{+} \gamma \delta$ T cells and CD94 ${ }^{+}$ $\mathrm{NKG}_{2} \mathrm{~A}^{+} \gamma \delta \mathrm{T}$ cells were, in contrast, lower in patients with SLE compared with HC $(p<0.001)$ [87]. In another study, PB-derived $\gamma \delta \mathrm{T}$ cells were isolated from 14 healthy volunteers and 22 SLE patients before and after 4 and 12 weeks following the onset of glucocorticoids (GC), mycophenolate mofetil (MMF), or hydroxychloroquine (HCQ) treatment. PB $\gamma \delta \mathrm{T}$ cells in general, and $\mathrm{V} \gamma 9^{+} \gamma \delta \mathrm{T}$ cells and $\mathrm{TNF} \alpha / \mathrm{IL}-17$-secreting $\mathrm{CD}^{-} \mathrm{CD}^{-} \gamma \delta \mathrm{T}$ cell subsets, in particular, were decreased in SLE compared to HCs, but the numbers of the $\gamma \delta \mathrm{T}$ cell subsets reached levels similar to those of HCs in responders, but not in non responders, to therapy. There was an inverse correlation between SLEDAI scores and $\gamma \delta \mathrm{T}$ cell c ompartments, especially with respect to $\mathrm{TNF} \alpha^{+} \gamma \delta \mathrm{T}$ cells, $\mathrm{TNF} \alpha^{+} \mathrm{V} \gamma 9^{+} \gamma \delta \mathrm{T}$ cells and IL-17+ CD4-CD8 ${ }^{-} \gamma \delta \mathrm{T}$ cell subsets and complement component 3 levels positively correlated with IL-17 producing $\gamma \delta \mathrm{T}$ cells [88]. In a study addressing subsets of $\gamma \delta \mathrm{T}$ cells, a significant decrease in the proportions of total $\gamma \delta \mathrm{T}$ cells and the V $\delta 2$ subset in new-onset SLE patients in comparison with HCs was found $(p=0.016$ for $\gamma \delta \mathrm{T}$ cells, $p=0.003$ for the V $\delta 2$ subset, along with an increased V $\delta 1$ proportion in inactive SLE patients $(p=0.004)$. The proportion of the $\mathrm{CD}_{2} 7^{+} \mathrm{CD} 45 \mathrm{RA}{ }^{-}$subset (central memory $\gamma \delta \mathrm{T}$ cells), was significantly reduced in both active and inactive SLE patients compared with HC. Absolute $\gamma \delta \mathrm{T}$ cell counts were also significantly decreased in active SLE patients, as were the $\mathrm{V} \delta 1$ and V $\delta 2$ subsets. Upon treatment, however, $\gamma \delta \mathrm{T}$ cell counts increased to normal levels with V $\delta 1$ cell counts increasing to levels higher than those observed in healthy donors. Although V $\delta 2$ cell counts rose to some extent, they remained significantly lower than in healthy donors. Furthermore, there was a negative correlation between the SLE Disease Activity Index (SLEDAI) and V $\delta$ and V $\delta 2$ $\gamma \delta \mathrm{T}$ cell counts. CD27 ${ }^{+} \mathrm{CD}_{45 \mathrm{RA}^{+}} \gamma \delta \mathrm{T}$ cell numbers also negatively correlated with the SLEDAI. $\mathrm{CD}^{2} 7^{+} \mathrm{CD} 45 \mathrm{RA}^{-} \mathrm{V} \delta$ cells displayed Foxp3, suggesting their regulatory potential and Foxp3 mRNA in $\gamma \delta$ T cells was markedly augmented following transforming growth factor (TGF) $\beta$ treatment in vitro. Furthermore, Foxp $3^{+} \gamma \delta \mathrm{T}$ subsets suppressed $\mathrm{CD} 4^{+} \mathrm{T}$ cells, suggesting these cells could modulate disease activity via suppression of pathogenic $\mathrm{CD}^{+} \mathrm{T}$ cells [89]. In contrast to $\mathrm{PB}$, the percentage of $\gamma \delta \mathrm{T}$ lymphocytes in the skin of SLE patients, was twice higher $(22.0 \pm 9.5 \%)$ than in the skin of healthy persons $(11.1 \pm 5.5 \%)(p<0.002)$ and a higher percentage was noted in patients with active disease $(27.0 \pm 9.4 \%)$ than in non-active SLE $(16.6 \pm 5.6 \%)(p<0.002)$. Similar differences were noted in the percentage of $\mathrm{V} \delta 2^{+}$and $\mathrm{V} \gamma 9^{+}$subpopulations in SLE patients when compared to healthy persons. With respect to the V 83 subset, a higher percentage was observed in patients with active SLE (10.5 $\pm 4.8 \%)$ than in patients with non-active SLE $(6.8 \pm 3.5 \% ; p<0.03)$ and in healthy persons $(3.6 \pm$ $3.1 \%, p<0.02)$. By contrast, $\mathrm{CD}^{+}$lymphocytes in the skin of SLE patients and healthy persons was, however similar $(81.4 \pm 7.9$ and $83.0 \pm 13.4 \%$, respectively; $p>0.05)$. Furthermore, there was a positive correlation between the percentage of $\gamma \delta \mathrm{T}$ lymphocytes in the skin and the activity of the disease $(\mathrm{r}=0.594, p<0.001)$. Confirming previous studies, there was a significantly lower number of $\gamma \delta \mathrm{T}$ cells in PB of SLE patients $(26.4 \pm 16.9 / \mathrm{mL})$ than in healthy persons $(55.3 \pm 20.6 / \mathrm{mL})(p<0.001)$ but no statistically significant correlation between the concentration of these cells and clinical activity of 
the disease was found [90]. Thus, $\gamma \delta$ T cells and their subsets are depleted in the PB of SLE patients, in inverse correlation with measures of disease activity (Table 1). 
Table 1. Changes of $\gamma \delta \mathrm{T}$ cells in autoimmune rheumatic diseases.

\begin{tabular}{|c|c|c|c|c|}
\hline Disease (Tissue) & Total $\gamma \delta$ T Cells (Relative to Normal) & $\begin{array}{c}\mathrm{V} \delta 1^{+} \mathrm{T} \text { Cells } \\
\text { (Relative to Normal) }\end{array}$ & V $\gamma 9 \mathrm{~V} \delta 2$ T Cells (Relative to Normal) & References \\
\hline $\mathrm{RA}(\mathrm{PB})$ & Equal or decreased & $\begin{array}{l}\text { Ratio relative to } \mathrm{V} \delta 2 \text { is } \\
\text { increased. Sometimes includes } \\
\text { oligoclonal expansions }\end{array}$ & $\begin{array}{l}\text { Equal or decreased (in established long term } \\
\text { disease), increased } V \gamma \delta \mathrm{V} \delta 2 \mathrm{TEMRA} \text {, decreased } \\
\text { naïve } \mathrm{V} \gamma \mathrm{V} \delta 2 \mathrm{~T} \text { cells. Sometimes include } \\
\text { oligoclonal expansions. Increases noted after } \\
\text { anti TNF } \alpha \text { and gold salt therapy. Negative } \\
\text { association with disease activity }\end{array}$ & \\
\hline RA (synovium) & $\begin{array}{l}\text { Polyclonal repertoire sometimes } \\
\text { containing oligoclonal expansions } \\
\text { common to different joints. HLADR } \\
\text { expression increased, CD16 decreased. }\end{array}$ & $\begin{array}{l}\text { Increased relative to V } \delta 2 \text {. Often } \\
\text { using } V \gamma 8 \text { or } V \gamma 3 \text { along with } \\
\text { V } \delta 1 \text { in the TCR }\end{array}$ & $\begin{array}{l}\text { Relatively expanded compared to the PB, } \\
\text { may use J } \delta 2 \text {. }\end{array}$ & [32] \\
\hline JIA (PB) & $\begin{array}{l}\text { May be Increased in oligoarticular and } \\
\text { quiescent systemic JIA otherwise equal. } \\
\text { Increase of IL-17 producers in SJIA }\end{array}$ & Increase of $\mathrm{V} \delta 1^{+} \mathrm{CD} 69^{+} \mathrm{T}$ cells & Increase of $\mathrm{V} \delta 2^{+} \mathrm{CD} 69^{+} \mathrm{T}$ cells & [71] \\
\hline JIA (synovium) & $\begin{array}{l}\text { Higher than PB in oligoarticular JIA. } \\
\text { Otherwise equal to percentage in PB }\end{array}$ & $\begin{array}{l}\text { Higher CD69+ than in PB, } \\
\text { usually } \mathrm{CD} 45 \mathrm{RA}^{+} \text {, higher in } \\
\mathrm{ANA}^{+} \text {patients, inversely } \\
\text { associated with age at onset, } \\
\text { and with recurrence of synovitis }\end{array}$ & $\begin{array}{l}\text { Higher } \mathrm{CD} 69^{+} \text {than } \mathrm{PB} \text {. Usually } \mathrm{CD} 45 \mathrm{RO}^{+} \\
\text {inversely associated with age at onset, } \\
\text { positively with recovery }\end{array}$ & [74] \\
\hline AS (pB) & $\begin{array}{c}\text { Total decreased, but enriched for IL23R }{ }^{+} \\
\gamma \delta \mathrm{T} \text { cells secreting IL-17 } \\
\text { and in IL-17 and GM-CSF double } \\
\text { producing } \gamma \delta \text { T cells }\end{array}$ & & $\begin{array}{l}\text { Elevated in AS patients receiving anti TNF } \alpha \text {, } \\
\text { secrete IFN } \gamma \text {. }\end{array}$ & {$[80,82-84]$} \\
\hline AS (enthesium/synovium) & $\begin{array}{l}\mathrm{ROR} \gamma \mathrm{t}^{+} \text {iNKT and } \gamma \delta \text {-hi T cells } \\
\text { increased, producing IL-17 }\end{array}$ & $\begin{array}{l}\text { Enriched for IL-23+ ROR } \gamma \mathrm{t}^{+} \\
\text {iNKT and } \gamma \delta \text {-hi }\end{array}$ & & {$[80,82-84]$} \\
\hline $\operatorname{SLE}(\mathrm{pB})$ & $\begin{array}{l}\text { Decreased, but increase of } \gamma \delta \text { T cells } \\
\text { expressing CD69 and HLADR, and } \\
\text { decrease of TNF } \alpha \text { and IL-17 secreting } \\
\text { cells. Inverse correlation with disease } \\
\text { activity. } \gamma \delta \text { lines help anti DNA } \\
\text { production by B cells }\end{array}$ & $\begin{array}{l}\text { decreased, but increased in } \\
\text { inactive SLE }\end{array}$ & decreased & {$[18,87,88]$} \\
\hline
\end{tabular}


Table 1. Cont

\begin{tabular}{|c|c|c|c|c|}
\hline Disease (Tissue) & Total $\gamma \delta$ T Cells (Relative to Normal) & $\begin{array}{c}\mathrm{V} \delta 1^{+} \mathrm{T} \text { Cells } \\
\text { (Relative to Normal) }\end{array}$ & V $\gamma 9 \mathrm{~V} \delta 2$ T Cells (Relative to Normal) & References \\
\hline SLE (skin) & increased & & increased & [90] \\
\hline SSc $[\mathrm{pB})$ & $\begin{array}{l}\text { Decreased especially in early term } \\
\text { disease (less than } 3 \text { years), diffuse disease } \\
\text { and in SCL7 } 0^{+} \text {patient. Otherwise equal. }\end{array}$ & $\begin{array}{c}\text { Increased } \mathrm{V} \delta 1^{+} \text {and } \\
\mathrm{CD} 161^{+} \mathrm{V} \delta 1^{+} \text {especially in } \\
\text { patients without ILD. Increase } \\
\text { of } \mathrm{V} \delta 1^{+} \mathrm{CD} 49 \mathrm{~d}^{+} \text {, and HLADR }{ }^{+} \\
\text {cells. May be profibrotic } \\
\text { in vitro, may respond to } \\
\text { cardiolipin via CD1d }\end{array}$ & $\begin{array}{l}\text { Unchanged, decreased, or increased in some } \\
\text { patients with ILD, increased granzyme } \\
\text { expression, cytotoxic to endothelial cells. } \\
\text { Induce fibroblast apoptosis. May be anti fibrotic. }\end{array}$ & [91] \\
\hline SSC (skin) & & Increased, restricted clonality & & {$[88,90,92-95]$} \\
\hline
\end{tabular}




\subsection{In Vitro Studies of $\gamma \delta T$ Cells from SLE Patients}

$\mathrm{T}$ cell lines were derived from a patient with subacute cutaneous lupus after treatment with intravenous pulse cyclophosphamide by selection of mitotically active, hypoxanthine-guanine phospho-ribosyltransferase-deficient (HPRT-D) $\mathrm{T}$ cells in a medium containing 6-thioguanine. When HPRT-D cell lines were derived 6 days after pulse cyclophosphamide (CYC) treatment, they were predominantly $\mathrm{CD}^{+}$and TCR $\gamma \delta^{+}$, and produced IFN $\gamma$. Cell lines derived 21 days after CYC treatment were in contrast $\mathrm{CD} 4^{+}, \mathrm{TCR} \alpha \beta^{+}$and produced both IFN $\gamma$ and IL-4, suggesting involvement of mitotically active $\gamma \delta$ and $\alpha \beta$ T cells at different phases of the disease [96]. Further evidence for the relevance of $\gamma \delta$ T cells came from a study of a total of 396 IL-2-dependent T-cell lines from the in vivo activated T cells of 5 patients with lupus nephritis. Only $59(\sim 15 \%)$ selectively augmented the production of pathogenic anti-DNA autoantibodies that were IgG in class, cationic in charge, specific for native DNA, and clonally restricted in spectratype. Forty-nine of the autoantibody-inducing Th lines were $\mathrm{CD}^{+}$and expressed the $\alpha \beta$ TCR. The other 10 were $\mathrm{CD} 4^{-} 8^{-}$, of which 3 expressed the $\alpha \beta$ TCR and 7-the $\gamma \delta$ TCR. The autoreactive responses of the $\mathrm{CD}^{+}{ }^{+}$Th lines were restricted to HLA class II antigens, whereas endogenous heat shock or stress proteins of the HSP60 family that were expressed by the lupus patients' B cells were involved in stimulating an autoreactive proliferation of the $\gamma \delta$ Th cells. These autoantibody-inducing $\mathrm{CD}^{-} 8^{-} \gamma \delta$ Th lines proliferated in response to HLA-mismatched antigen presenting cells from lupus patients but not normal subjects, and could also provide HLA-nonrestricted help for production of IgG anti-dsDNA autoantibodies by B cells from unrelated lupus patients. The autoreactive response of the $\gamma \delta$ Th lines but not the $\alpha \beta$ Th lines, could be blocked partially or completely by mAbs to the $65-\mathrm{kDa}$ HSP whereas anti-HSP70 mAb had no significant effect. These studies demonstrated helper activity of certain $\gamma \delta \mathrm{T}$ cells in SLE [92]. From these studies, it is clear that $\gamma \delta$ T cells of SLE patients harbor the potential to affect disease by encouraging the production of pathogenic anti DNA antibodies by patient $\mathrm{B}$ cells.

\section{Murine Models}

\subsection{MRL/lpr Model}

The congenic MRL/Mp-lpr/lpr strain develops a rapid form of MRL lupus, including the accumulation of $\mathrm{CD}^{-} \mathrm{CD}^{-}{ }^{-} \mathrm{B} 220^{+} \mathrm{T}$ cells, due to a defect in the Fas apoptosis gene. Eight groups of homozygotic MRL/lpr mice, including TCR $\beta^{+/+}$or TCR $\beta^{-/-}, \mathrm{TCR} \delta^{+/+}$or TCR $\delta^{-/-}$, and Fas ${ }^{+/+}$or Ipr/lpr were studied. $\gamma \delta \mathrm{T}$ cell-deficient animals developed exacerbated disease, as evaluated by hyperglobulinemia, autoantibody titers, renal disease, and mortality, demonstrating a role for $\gamma \delta$ $\mathrm{T}$ cells in the regulation of systemic autoimmunity. Thus, TCR $\delta^{-}$lpr mice consistently developed accelerated and more severe disease than $\mathrm{TCR} \beta^{+} \delta^{+}$animals, as typified by glomerulonephritis, interstitial infiltrates, and perivasculitis, an effect more apparent in younger mice. Conventional CD4 ${ }^{+}$ $\mathrm{T}$ cells were polyclonally expanded in these animals at the expense of classical lpr CD4 ${ }^{-} \mathrm{CD} 8^{-} \mathrm{B} 220^{+}$ $\mathrm{T}$ cells, suggesting that $\gamma \delta \mathrm{T}$ cells regulate autoimmune responses by altering $\mathrm{T}$ cell development. $\gamma \delta \mathrm{T}$ cell-deficient animals of both $\mathrm{Fas}^{+}$and lpr genotypes develop higher intensity as well as higher titer autoantibodies than their TCR $\beta \delta^{+}$counterparts. On the other hand, whereas TCR $\beta^{-} \gamma^{-}$sera contained no detectable antinuclear antibodies, TCR $\beta^{-}$lpr mice, developed an incompletely penetrant autoimmune syndrome, suggesting that $\gamma \delta \mathrm{T}$ cells themselves were responsible for the development of elevated autoantibody titers in these animals. While mice possessing either $\alpha \beta$ or $\gamma \delta$ T cells were capable of producing substantial IL-2, IL-4, IFNy, and IL-10, TCR $\beta-\delta^{-}$mice failed to produce IL-2 or IL- 4 and generated greatly reduced levels of IFN $\gamma$ and IL-10. Thus, $\gamma \delta$ T cells in this autoimmune model of SLE have the capacity to provide T-dependent help and or regulation via cytokine production [97]. In another study of MRL/lpr mice $\mathrm{CD} 4^{+} \mathrm{B} 220^{+}$cells accumulated during aging of mice and development of SLE, when they consist up to $5 \%$ of splenocytes. Of these, about $32 \%$ were found to express $\gamma \delta$ TCR and produce IL-17. Furthermore, $\mathrm{CD} 4^{+} \mathrm{B} 220^{+}$producing cells could enhance the proliferation of conventional $\mathrm{CD} 4^{+} \mathrm{B} 220^{-}$pathogenic cells [98]. Mechanisms involved in the effects of $\gamma \delta \mathrm{T}$ cells in 
the MRL/lpr model were further explored in the Blk \pm .lpr mouse, in which Blk expression levels are reduced to levels comparable to those in individuals carrying a risk allele for BLK, which encodes B lymphoid kinase, a susceptibility gene for SLE, resulting in reduced gene expression. BLK was found to be expressed in IL17 ${ }^{+} \gamma \delta$ T cells, as well as B cells and ROR $\gamma^{+} \mathrm{DN} \alpha \beta$ cells and pDC. At 5 months of age, $60 \%$ of the $\mathrm{Blk}^{+/-}$.lpr mice, but none of the B6.lpr mice, displayed proteinuria. While there was no mesangial proliferation or any other signs of immune complex (IC)-induced inflammation or difference in the serum levels of ANAs between 5-month-old B6.lpr and Blk ${ }^{+-}$.lpr mice, there was narrowing of the capillary lumens and hyaline deposits were found in the glomeruli of Blk ${ }^{+/}$.lpr mice but not in those of B6.lpr mice, as was damage to the podocyte, a component of the glomerular filtration barrier. Thus, 5-month-old Blk ${ }^{+/}$.lpr mice suffered from nephrosis, a kidney disease that is frequently observed in SLE patients with renal involvement due to lupus podocytopathy. In the $\mathrm{BLK}^{+/}$.lpr mice there were more IL-17 and IFN $\gamma$ secreting $\gamma \delta$ T cells. These findings suggest that BLK risk alleles confer susceptibility to SLE through the dysregulation of a proinflammatory cytokine network including $\gamma \delta$ $\mathrm{T}$ cells [93]. Another mechanism of $\gamma \delta \mathrm{T}$ cell involvement might be attributed to $\gamma \delta \mathrm{T}$ cell mediated apoptosis. Thus, it has been shown that the phosphopeptide P140 issued from the spliceosomal U1-70K small nuclear ribonucleoprotein (snRNP) protein is recognized by lupus $\mathrm{CD} 4^{+} \mathrm{T}$ cells, transiently abolishes T cell reactivity to other spliceosomal peptides in P140-treated MRL/lpr mice and ameliorates their clinical features. P140 peptide binds the constitutively-expressed chaperone HSC70 protein and induces apoptosis of activated MRL/lpr CD4 ${ }^{+} \mathrm{T}$ cells. When nine-week-old MRL/lpr mice received two successive intraperitoneal and intravenous administrations of anti-pan TCR $\gamma \delta \mathrm{mAb}$ eight and three days before P140 treatment, P140 induced no PBL apoptosis contrasting to its affect in untreated mice. Thus, in vivo P140 induces PBL apoptosis, leading to amelioration of SLE in MRL/lpr mice via a mechanism involving $\gamma \delta$ T cells [94]. From these studies, salient features of which are summarized in Table 2, it is apparent that in the MRL/lpr model of autoimmunity resembling human SLE, $\gamma \delta$ play both a regulatory role dampening pathogenic effects of $\alpha \beta$ T cells, perhaps via apoptotic mechanisms, but may also have, in situations in which conventional $\mathrm{T}$ cells are suppressed, a pathogenic role that is partly controlled by the BLK gene.

\subsection{NZB/NZW Model}

In this model, CD1d-dependent $\mathrm{T}$ cells were depleted in order to investigate the role of these cells in genetically lupus-prone NZB/NZW F1 (BWF1) mice, by injections of 50 million irradiated CD1d-transfected A20 cells. This resulted in $50-75 \%$ reduction in NK1. $1^{+}$T cells, including CD $4^{+} \mathrm{NK} 1.1^{+}$, NK1.1 ${ }^{+} \mathrm{CD} 122^{+}$or NK1.1 ${ }^{+} \mathrm{CD} 62 \mathrm{~L}-\mathrm{T}$ cells and NK1.1 ${ }^{+} \mathrm{TCR} \gamma \delta^{+} \mathrm{T}$ cells. This depletion of CD1d-reactive $\mathrm{T}$ cells in preclinical BWF1 mice resulted in disease acceleration with a significant increase in proteinuria and mortality. In older BWF1 mice having advanced nephritis, however, depletion resulted in some disease improvement. Thus, similar to the findings in the MRL/lpr model, and suggested by some of the human functional studies, $\gamma \delta \mathrm{T}$ cells bearing receptors that recognize CD1d-lipids along with other types of CD1d dependent T cells may participate in pathogenic and protective roles in SLE [99].

\subsection{Pristane Induced Model}

In a study of 8-week-old C57BL/ 6 and TCR $\delta^{-/-}$mice that received a single i.p. injection of $0.5 \mathrm{~mL}$ of pristine, the TCR $\delta^{-/-}$mice developed milder glomerulonephritis, consistent with their decreased serum levels of lupus-related autoantibodies, when compared with wild type mice. It was also found that injection of CFA, but not alum immunization induces a subpopulation of CXCR5-expressing $\gamma \delta \mathrm{T}$ cells in the draining lymph nodes. TCR $\gamma \delta^{+} \mathrm{CXCR}^{+}$cells presented antigens to, and induced CXCR5 on, CD4 T cells by releasing Wingless-related integration site (Wnt) ligands to initiate the $\mathrm{T}$ follicular helper (Tfh) cell program. Accordingly, TCR $\delta^{-1-}$ mice had impaired germinal center formation, inefficient $\mathrm{Tfh}$ cell differentiation, and reduced serum levels of chicken ovalbumin (OVA)-specific antibodies after CFA/OVA immunization, suggesting that modulation of SLE by $\gamma \delta \mathrm{T}$ cells is also mediated by their ability to control TfH cell differentiation [100]. In addition, in the same model of pristane-induced SLE, 
increased IL-17F and IL-17A expression was found in renal CD4 ${ }^{+} \mathrm{T}$ cells and $\gamma \delta \mathrm{T}$ cells. Moreover, in this chronic model SLE, IL-17F-deficient mice developed less severe disease than wild-type mice, with respect to survival and renal injury. IL-17F induced expression of the neutrophil-attracting chemokines CXCL1 and CXCL5 in kidney cells, suggesting a role for IL-17 producing $\gamma \delta$ T cells and Th17 cells in recruitment of neutrophils involved in renal inflammation in SLE [101]. A summary of the mode of participation of $\gamma \delta \mathrm{T}$ cells in SLE, including data from human and murine studies is presented in Tables 1 and 2 and, in graphic and tabular forms in Figure 2 and Table 2.

Table 2. $\gamma \delta$ T cells in animal models of autoimmune rheumatic diseases.

\begin{tabular}{ccc}
\hline Disease Model & Role of $\gamma \delta$ T Cells & References \\
\hline Rat adjuvant arthritis & $\begin{array}{c}\text { No role in disease induction. Possible role } \\
\text { in effector phase of disease. }\end{array}$ & [52-55] \\
\hline Murine Collagen induced arthritis & $\begin{array}{c}\mathrm{V} \gamma 4 / \mathrm{V} \delta 4^{+} \text {cells producing IL-17 are pathogenic. IL-17 } \\
\text { production can be suppressed by inhibitor of ROR } \gamma \mathrm{t} \\
\text { and by IL-28A. ES-62, a phosphorylcholine } \\
\text { containing glycoprotein and IL-10 reduce migration } \\
\text { of IL-17 producing } \gamma \delta \text { T cells to the inflamed joint, } \\
\text { which are maintained by IL-23, and are not } \\
\text { associated with bone destruction. }\end{array}$ \\
\hline Murine BSA induced arthritis & [58] \\
& $\begin{array}{c}\text { (ROR } \gamma) t^{+} \text {IL-17 producing } \gamma \delta \text { T cells dependent } \\
\text { upon IL-23 accumulated in arthritic joints. }\end{array}$ \\
\hline
\end{tabular}

IL-1R and IL-23R expressing $\mathrm{V} \gamma 6^{+} \gamma \delta$ IL 17 cells are the main producers of IL-17 in joints of II1 $\mathrm{rn}^{-} \%$ mice spontaneously developing arthritis. $\gamma \delta \mathrm{T}$ cells are

Murine non antigen dependent arthritis responsible for arthritis in B10.RIII mice induced by gene transfer of IL-23. Arthritis induced by intraperitoneal injection of mannan is dependent upon IL-17 secreting $\gamma \delta$ T cells.

IL-17 secreting $\gamma \delta$ T cells were shown to participate in arthritis and the systemic response to complete Freund adjuvant injection developing in these mice.

increased number of $\gamma \delta \mathrm{T}$ cells are found in Achilles

Murine IL-23 gene introduction tendon enthesis, aortic root, and adjacent to the

Murine IFN $\gamma^{-}$knockout (KO)

$$
\text { ciliary body and secreted IL-17. }
$$
glomerulonephritis in the presence of $\alpha \beta$ T cells, but mediate a less severe form of disease in their absence, mediated by cytokines and help for B cells. With age, some $\gamma \delta$ T cells acquire a CD $4^{+} \mathrm{B} 220^{+}$

Murine MRL/lpr model of SLE phenotype, and produce IL-17. In BLK ${ }^{+/-}$.lpr mice expressing low levels of Bruton lymphocyte kinase gene IL-17 and IFN $\gamma$ producing $\gamma \delta$ T cells are increased enhanced and mediate glomerular damage. $\gamma \delta$ T cells induce phosphopeptide P140 mediated apoptosis of lymphocytes, which is associated with amelioration of disease in MRL/lpr mice. $\begin{array}{cc}\text { lupus-prone NZB/NZW mice } & \begin{array}{c}\text { CD1d restricted } \gamma \delta \mathrm{T} \text { cells may be protective in } \\ \text { young, and pathogenic in old mice. }\end{array}\end{array}$

$\gamma \delta \mathrm{T}$ cells in the kidney expressed IL-17F and A and attracted neutrophils to the kidney. TCR $\delta^{-1-}$ mice developed milder glomerulonephritis, due to decreased $\mathrm{T}$ follicular helper cell differentiation dependent upon $\gamma \delta$ T cell secretion of Wnt ligands. 


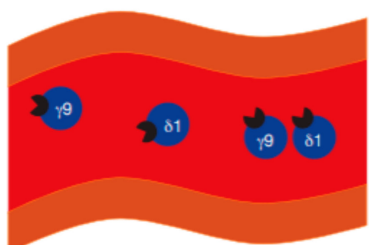

Remission after therapy

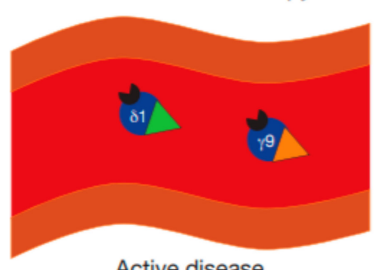

Active disease

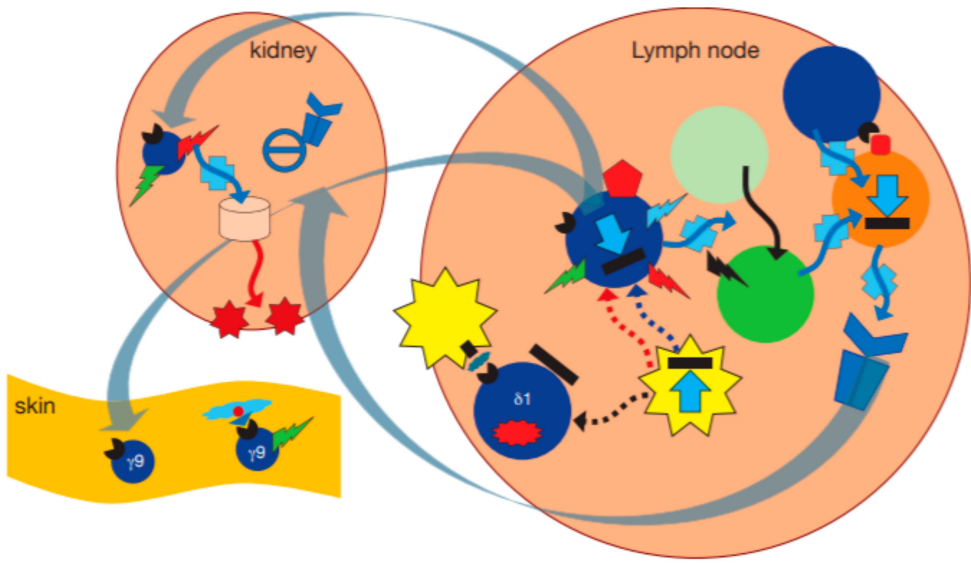

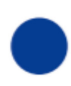
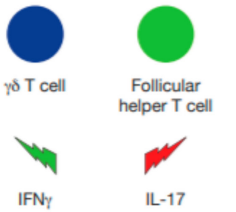

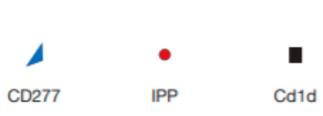

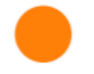

B cell

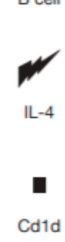

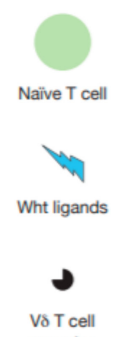

Vo T cell
receptor
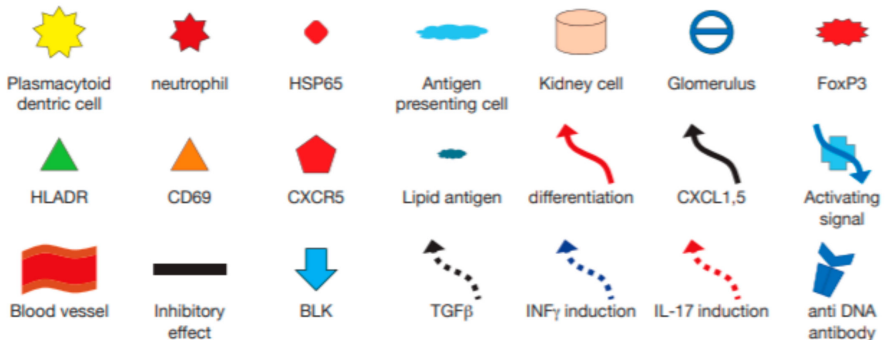

Figure 2. Hypothetical model incorporating the immunopathogenetic role of $\gamma \delta \mathrm{T}$ cells in human systemic lupus erythematosus (SLE) and murine models. $\gamma \delta \mathrm{T}$ cells may become activated by plasmacytoid dendritic cells pDC in lymph nodes, leading to their secretion of proinflammatory cytokines such as IL-17 and IFN $\gamma$, an activity modulated by BLK [93]. A subset of $\gamma \delta \mathrm{T}$ cells expressing CXCR5 release Wingless-related integration site (Wnt) proteins, that enhance differentiation of naïve $\mathrm{T}$ cells to become follicular helper T cells [100], which in turn, together with IL-4 secretion [97] differentiate B cells to become antigen producing cells making anti DNA antibodies. Other $\gamma \delta \mathrm{T}$ cells directly interact with heat shock protein (HSP)65 expressing B cells via their T cell receptor (TCR) and help drive anti DNA antibody secretion [92]. At the same time regulatory FoxP3 ${ }^{+} \gamma \delta \mathrm{T}$ cells may become activated by transforming growth factor (TGF) $\beta$ produced by $\mathrm{pDC}$ [18], and by CD1d expressing cells in a TCR dependent manner, to downregulate the immune response [99]. After activation in lymph nodes, $\gamma \delta \mathrm{T}$ cells could migrate to the kidney where they secrete IL-17, thus enhancing migration of leukocytes [101].

\section{Systemic Sclerosis}

\section{1. $\gamma \delta T$ Cells in PB and Tissue of SSc Patients}

Patients whose serum contained anti Scl-70 antibodies and patients with shorter disease duration had reduced number of $\gamma \delta \mathrm{T}$ cells in PBMC compared with controls ( $p<0.05$ and $p<0.01$, respectively). Absolute values of $\gamma \delta \mathrm{T}$ cells were lowest for patients with a disease duration of less than three years $(14.2 \pm 5.9$ vs. $37.5 \pm 12.5)$ cells $/ \mathrm{mm}^{3}$, those with anti-Scl-70 antibodies $(23.9 \pm 10.4$ vs. $30.3 \pm 11.5)$ cells $/ \mathrm{mm}^{3}$ and those with diffuse disease $\left(23.7 \pm 7.2 \mathrm{vs.} 40.3 \pm 25.1 \mathrm{cells} / \mathrm{mm}^{3}\right)$. There was no significant difference in the proportion or absolute number of CD56 cells or $\gamma \delta \mathrm{T}$ cells between patients receiving or not receiving steroid medications. The proportion of $\gamma \delta \mathrm{T}$ cells was also significantly lower in the patient group $(1.61 \pm 0.52 \%$ vs. control $2.61 \pm 0.46 \%(p<0.05)$. Again, patients with early disease or with anti-Scl-70 antibodies accounted for the reduction of the proportion of $\gamma \delta \mathrm{T}$ cells [91]. In another study, 50 patients with SSc had lower values (both percentage and absolute number) of NKT cells ( $p<$ 0.01 and $p<0.003$, respectively) and of $\gamma \delta$ T cells ( $p<0.01$ and $p<0.005$, respectively) [102]. In yet another cohort of 12 patients with SSc, when compared to 16 healthy volunteer donors, it was found that the $\mathrm{V} \delta 1^{+} \gamma \delta$ T cell subset had significantly enhanced expression of both HLA-DR (83\% of total V $\delta 1^{+}$ 
cells) and CD $49 \mathrm{~d}\left(90 \%\right.$ of total V $81^{+}$cells) compared with the controls ( $20.5 \%$ and $60 \%$, respectively). The percentage of total $\mathrm{V} \delta 1^{+} \gamma \delta \mathrm{T}$ cells was also enhanced (2.7 vs. $\left.0.8 p<0.005\right)$, whereas the percent of total $\gamma \delta$ T cells was similar to controls. Percentages and absolute numbers CD16, CD8, CD45RO, CD25, HLA-DR, CD54, and CD11a on total $\gamma \delta \mathrm{T}$ cells did not differ significantly from controls whereas CD $49 \mathrm{~d}^{+} \gamma \delta \mathrm{T}$ cells were significantly increased in the patients $(2.3 \%)$ compared with controls $(0.5 \%)$. In the skin, the absolute numbers of $\gamma \delta \mathrm{T}$ cells were found in striking amounts in perivascular areas, particularly in the early edematous phase of SSc (22.58 in patients and 0 in controls); the majority of $\gamma \delta \mathrm{T}$ cells were $\mathrm{V} \delta 1^{+}$(19 in patients and 0 in controls). Moreover, even in the advanced phase of SSc, $\mathrm{V} \delta 1^{+} \mathrm{T}$ cells were also increased compared with controls (3.5 versus 0 ) [95]. In another study, however, the percent of $\mathrm{V} \delta 1^{+} \gamma \delta \mathrm{T}$ cells was significantly elevated among the PB T cells in patients without radiographic evidence of interstitial lung disease (ILD) but not in those with $\operatorname{ILD}(n=7)$. $V \gamma 9^{+} \mathrm{T}$ cells were equally and persistently represented in the PB of patients irrespective of pulmonary disease or cyclophosphamide treatment, at levels similar to HC [103]. Interestingly, supporting this finding, the proportion of $\mathrm{CD} 161^{+} \mathrm{V} \delta 1^{+} \gamma \delta \mathrm{T}$ cells in PBMCs from the HCs, RA patients, and PM/DM was significantly lower than in SSc patients and similar results were found with regard to the absolute number of $\mathrm{CD}_{161^{+}} \mathrm{V} \delta 1^{+} \gamma \delta \mathrm{T}$ cells in PBMCs. Furthermore, the proportion of $\mathrm{CD} 161^{+} \mathrm{V} \delta 1^{+} \gamma \delta \mathrm{T}$ cells was significantly higher in IP-negative SSc patients compared with IP-positive SSc patients and HCs. However, CD $161^{+} \mathrm{V} \delta 1^{+} \gamma \delta \mathrm{T}$ cells were not altered by the presence of IP in patients with RA and PM/DM suggesting a disease specific relationship [104]. In another study, although no significant difference in number and proportion of $\gamma \delta \mathrm{T}$ cells was observed in SSc patients compared to HC, geometric mean fluorescence intensity (GMFI) of CD16 and CD69 on $\gamma \delta \mathrm{T}$ cells was significantly increased in patients with diffuse cutaneous SSc (dcSSc) compared to HCs while CD62L expression was significantly decreased. Additionally, $\gamma \delta$ T cell infiltrations were observed in SSc patients' skin [105]. In yet another study, absolute numbers of $\gamma \delta$ T-cell subsets were, like some of the other reports cited above, were found to be significantly decreased in SSc patients, which was thought to reflect their mobilization to the inflamed skin. In addition, patients with pulmonary fibrosis showed a biased TCR repertoire, with a selected expansion of effector $V \gamma 9^{+} \gamma \delta \mathrm{T}$ cells [106]. In summary, despite a general reduction of $\gamma \delta \mathrm{T}$ cells in the PB of patients with diffuse disease, these data reveal a unique expansion of activated $\mathrm{V} \delta 1^{+} \mathrm{T}$ cells in SSc, which may be more pronounced in the absence of lung involvement. Moreover, these cells appear to express a CD161 ${ }^{+}$phenotype (Table 1$)$.

\subsection{Functions and Subsets of $\gamma \delta T$ Cells in SSc}

In assessing cytokine production and cytotoxic activity of circulating $\gamma \delta \mathrm{T}$ lymphocytes obtained from SSc patients and to evaluate their potential role during this disorder, both the proportion and the absolute number of IFN $\gamma$ producing $\gamma \delta$ T cells (i.e., displaying a Th1 polarization) in SSc were found to be significantly higher than the proportion and the absolute number of IL-4 producing $\gamma \delta$ - T cells in SSc, or the proportion and the absolute number of IFN $\gamma$-producing $\gamma \delta \mathrm{T}$ cells in $\mathrm{HC}(p<0.05$ for both groups). Furthermore, the cytotoxic activity of enriched $\gamma \delta$ T cells was significantly increased in SSc patients compared with controls. The results concerning the $\mathrm{V} \delta 1^{+} \mathrm{T}$ cell subset paralleled those of total $\gamma \delta \mathrm{T}$ lymphocytes. In contrast, $\alpha \beta$ T cells from SSc displayed greater Th 2 cytokine production. All these findings were independent of both disease subset and clinical status. Thus, although SSc is generally considered a Th2 autoimmune disease, Th1 polarization of $\gamma \delta$ T cells and an increase in their cytotoxic activity is observed in SSc, suggesting that $\gamma \delta$ T cells could have a relatively autonomous role in the pathogenesis in this disease [95].

Further functional studies revealed, in a study of $16 \mathrm{SSc}$ patients and $16 \mathrm{HCs}$, that ex vivo triggering of patient PB $\mathrm{V} \gamma 9^{+} \mathrm{T}$ cells with IPP plus IL-2-induced dose-dependent expansion, resulted in secretion of TNF $\alpha$, and contact-dependent apoptosis of co-cultured fibroblasts, at levels similar to $\mathrm{V} \gamma 9^{+} \mathrm{T}$ cells of controls [103]. In another study, isolated $\gamma \delta \mathrm{T}$ cells were then co-cultured with fibroblasts, and mRNA expressions of proalpha1(I) collagen and proalpha2(I) collagen (COL1A2) of fibroblasts were analyzed by real time RT-PCR. COL1A2 mRNA expression was significantly higher in fibroblasts cocultured with 
$\gamma \delta \mathrm{T}$ cells from SSc than that from HCs in cell contact independent manner [105]. In yet another study, $\gamma \delta$ T-cell subsets displayed a Th1-type cytokine responses. However, cytotoxic properties showed significant disease-associated and subset-specific changes. SSc patients exhibited increased percentages of $\mathrm{CD}_{2} 7^{+} \gamma \delta \mathrm{T}$ cells expressing granzyme (GZM) B or perforin and upregulated GZMA expression in diffuse cutaneous SSc. Conversely, Eomesodermin (EOMES) and NKG2D were downregulated in both SSc $\gamma \delta$ T-cell subsets vs. normal controls. Interestingly, patients with pulmonary fibrosis showed a biased TCR repertoire, with expansion of effector $\mathrm{V} \gamma 9^{+} \gamma \delta \mathrm{T}$ cells associated with increased frequency of cells expressing GZMB, but decreased IFN $\gamma$ production. The authors concluded that there is an increased cytotoxic activity and thus enhanced pathogenic potential of $\mathrm{CD}^{2} 7^{+} \gamma \delta \mathrm{T}$ cells in SSc [106]. These findings are supported by an early study, in which $\gamma \delta$ - and $\alpha \beta$-T cells were isolated from PB of SSc patients with early diffuse disease and of matched control subjects by an immunomagnetic method after stimulation with mycobacterium lysate and IL-2 for 2 weeks. It was found that SSc $\gamma \delta$-T cells adhered to cultured endothelial cells (EC) and proliferated at higher rates than control cells. Furthermore, significant EC cytotoxicity by SSc $\gamma \delta$ was seen. The cytotoxicity was blocked by addition of anti- $\gamma \delta$-TCR antibody and by anti-granzyme A antibody but not by anti-MHC class I and II antibodies. Expression of granzyme A mRNA was seen in five/five SSc $\gamma \delta-T$ cells and in one/five control cells. $\alpha \beta-\mathrm{T}$ cells from both SSc and control subjects were significantly less interactive with EC than $\gamma \delta$-T cells [107].

In another detailed study, 17 RA patients, 35 with SSc, 14 with polymyositis/dermatomyositis (PM/DM) and 22 disease-free HCs were analyzed. The proportion of CD $161^{+} \mathrm{V} \delta 1^{+} \gamma \delta \mathrm{T}$ cells in PBMCs correlated negatively with serum KL-6 values (indicative of active interstitial lung disease) among $\mathrm{IP}^{+}$ SSc patients, whereas that of total $\mathrm{V} \delta 1^{+} \gamma \delta \mathrm{T}$ cells and CD161-V $\delta 1^{+} \gamma \delta \mathrm{T}$ cells did not. As indicated above, the proportion of $\mathrm{CD} 161^{+} \mathrm{V} \delta 1^{+} \gamma \delta \mathrm{T}$ cells in PBMCs was higher in SSc in particular in IPpatients $(1.03 \% \pm 0.30)$ compared with $\mathrm{IP}^{+} \mathrm{SSc}$ patients. Intracellular staining of $\mathrm{PMA}^{+}$ionomycin triggered $\mathrm{V} \delta 1^{+}$cells from patients and controls revealed similar levels of IFN $\gamma$ and other cytokines. $\mathrm{CD}_{161}{ }^{+} \mathrm{V} \delta 1^{+} \mathrm{T}$ cells secreted more IFN $\gamma$ but not IL-4, IL-17, or TNF $\alpha$ than CD161- V $81^{+} \mathrm{T}$ cells in response PMA + ionomycin. However, in $\mathrm{IP}^{+}$patients, $\mathrm{CD} 161^{+} \mathrm{V} \delta 1^{+}$cell lines produced less IFN $\gamma$ than controls in response to triggering the TCR with anti V $\delta 1 \mathrm{mAb}$. Furthermore, CD161 ${ }^{+} \mathrm{V} \delta 1^{+} \gamma \delta$ $\mathrm{T}$ cell lines of IP- SSc patients produced a significantly greater amount of CCL3 (which abrogates inhibiting effects of IFN $\gamma$ on fibroblast proliferation) than $\mathrm{HC} \mathrm{CD} 161^{+} \mathrm{V} \delta 1^{+} \gamma \delta \mathrm{T}$ cell lines, upon TCR stimulation [104]. Given the important suggested role of $\mathrm{V} \delta 1^{+} \gamma \delta \mathrm{T}$ cells with respect to pulmonary fibrosis, outlined in these studies, it is of interest that an increased percentage of $\gamma \delta \mathrm{T}$ cells expressing the TCR V $\delta 1$ gene was detected in bronchoalveolar lavage fluid of patients with SSc. To estimate clonality of these $\mathrm{V} \delta 1^{+} \mathrm{T}$ cells, the diversity of $\mathrm{V} \delta 1$ junctional regions (V-D-J) was examined using RT-PCR to amplify TCR $\delta$-chain transcripts isolated from PBMC, lung, esophagus, stomach, or skin of patients and controls. Limited diversity of V81-J $\delta$ junctional regions in SSc patients was demonstrated by comparing the size distribution of PCR-amplified junctional region cDNA from patients with that of controls. Sequence analyses confirmed that V $\delta 1-J \delta$ junctional regions from the blood of SSc patients had less diversity than those from controls, in that a significantly higher proportion of sequences were repeated in patients ( $54.4 \%$ vs. $19.4 \%$ in controls). Evidence for selection of the $\mathrm{V} \delta 1^{+} \mathrm{T}$ cells in the tissues of SSC patients came from the findings that the same V $\delta 1-\mathrm{J} \delta$ junctional sequences persisted in an individual patient over time and that identical junctional sequences were isolated from multiple sites. Analysis of deduced amino acid sequences revealed two clusters of similarities among the junctional regions from patients. These data suggest that expansion of $\mathrm{V} \delta 1^{+} \gamma \delta \mathrm{T}$ cells may be antigenically driven in SSc patients [108]. Further evidence supported the idea that SSc V81 $1^{+} \mathrm{T}$ cells may recognize the autoantigen, cardiolipin in a CD1d dependent manner, and the outcome of this recognition is influenced by cross talk with activated $\mathrm{V} \gamma 9^{+} \mathrm{T}$ cells. Thus, in vitro, cardiolipin (CL) decreased CD25 on $\mathrm{V} \gamma 9 \mathrm{~T}$ cells from SSc patients, an effect which was abrogated by zoledronate. Zoledronate, on the other hand, decreased CD25 expression in SSc V $\delta 1 \mathrm{~T}$ cells uniquely, whereas CL abrogated this decrease. Moreover, anti CD1d abrogated CL induced enhancement of CD25 expression of SSc V 81 cells. CL also 
decreased IFN $\gamma$ secretion of SSc V $\delta 1^{+} \mathrm{T}$ cells relative to HC. Thus, CD1d mediated interactions of V $\delta 1^{+}$ $\mathrm{T}$ cells in SSc may play a profibrotic role via effects on pro and anti fibrotic cytokines, in particular in the context of simultaneous $\mathrm{V} \gamma 9^{+} \mathrm{T}$ cell triggering [109].

On the other hand, because of the functional cytokine producing and cytotoxic functions role of $\mathrm{V} \gamma 9^{+} \mathrm{T}$ cells in SSc detailed above, it was of interest, that an SSc patient was described whose condition worsened dramatically after an infusion of zoledronate. In vitro, zoledronate increased TNF $\alpha$ secretion by patient $\mathrm{V} \gamma 9^{+} \gamma \delta \mathrm{T}$ cells, and induced tissue factor-1 on monocytes, which could be abrogated by anti $\mathrm{TNF} \alpha \mathrm{mAb}$. Zoledronate also induced IL-4 production in SSc V $\delta 1^{+}$but not in $\mathrm{HC} \mathrm{V} \delta 1^{+} \mathrm{T}$ cells. These findings suggest mechanisms wherein activating $\mathrm{V} \gamma 9^{+} \gamma \delta \mathrm{T}$ cells in vivo could lead to deleterious effects in SSc [110]. On the other hand, when PBMC from SSc patients and HCs were stimulated by increasing concentrations of zoledronate, with or without IPP, and $V \gamma 9^{+} \mathrm{T}$ cell percentages were calculated using FACScan analysis it was found that higher concentrations of zoledronate were required for maximal proliferation of $\mathrm{V} \gamma 9^{+} \mathrm{T}$ cells in $9 \mathrm{SSc}$ patients compared to $9 \mathrm{HC}$. When compared to stimulation by toxic shock syndrome toxin (TSST)-1, a non-V $\gamma 9^{+}$selective reagent that activates $\alpha \beta$ T cells, secretion of the anti-fibrotic cytokines TNF $\alpha$ and IFN $\gamma$ in response to the $\mathrm{V} \gamma 9$ selective antigen IPP was relatively diminished in SSc compared to HC. In addition, reduction of procollagen secretion by fibroblasts cultured with supernatants of IPP-stimulated PBMC was observed in some SSc patients suggesting that although somewhat defective in their secretion of the anti fibrotic IFN $\gamma$, patient $\mathrm{V} \gamma 9^{+}$ $\mathrm{T}$ cells may maintain some, although insufficient, anti fibrotic characteristics [111]. Interestingly in this regard 18 patients with SSc received a single intravenous dose of $60 \mathrm{mg}$ of pamidronate and were followed for 6 months to assess effects on cytokine production by PBMC. Unstimulated PBMC produced increased amounts of IFN $\gamma$ and TNF $\alpha$ and reduced levels of TGF $\beta$ for up to 24 weeks after the infusion [112]. Taken together, these studies indicate important functional roles for $\gamma \delta \mathrm{T}$ cells in SSC patients. These cells, in particular the $\mathrm{V} \gamma 9^{+} \mathrm{V} \delta 2^{+}$subset, appear to be enriched for cytotoxic potential relative to $\mathrm{HC}$, and when activated which may manifest anti endothelial and anti fibroblastic potential, while simultaneously producing pro-coagulant inducing (TNF $\alpha$ ) and anti fibrotic (IFN $\gamma$ ) cytokines. In addition, the V $\delta 1$ subset, cells of which may be recognizing lipid antigens presented by CD1d, appears to be distributed oligoclonally in tissues, where they may act in a deleterious profibrotic capacity mediated in part by profibrotic factors such as IL-4, CCL3, while producing lower level of the anti fibrotic IFN $\gamma$ than healthy $\mathrm{V} \delta 1^{+} \mathrm{T}$ cells. Figure 3 shows, in graphic form, a model incorporating the above described modes of participation of $\gamma \delta$ T cells in SSc. A review of prevalent animal models of SSc the reader is available in reference [113]. 




Figure 3. Role of $\gamma \delta \mathrm{T}$ cells in human systemic sclerosis. On the right, representing patients without interstitial lung disease, are, cytotoxic granzyme expressing $\mathrm{V} \delta 2^{+} \gamma \delta \mathrm{T}$ cells in the peripheral blood, which are shown to interact with the endothelium via engagement of the TCR with CD277 endothelial molecules activated by isopentenyl pyrophosphate (IPP), while inducing the procoagulant tissue factor on monocytes, which together could lead to endothelial damage $[103,107]$. The peripheral blood is enriched in $\mathrm{CD} 161^{+} \mathrm{V} \delta 1^{+} \mathrm{T}$ cells [104]. Profibrotic V $\delta 1^{+}$cells may migrate to the lung, where they encounter cells expressing CD1d in complex with lipids, which trigger $\mathrm{V} \delta 1^{+} \mathrm{T}$ cells to secrete profibrotic factors (e.g., IL-4, CCL3) $[104,105,110]$. Along with this, exit of V $\delta 2^{+} \mathrm{T}$ cells (which may potentially confer anti fibrotic functions), from the lung to the peripheral blood takes place [106,111]. These alterations of $\gamma \delta \mathrm{T}$ cell composition in the lung may contribute to progressive lung disease.

\section{Concluding Remarks}

Interestingly, the lead authors of the first papers to describe $\gamma \delta \mathrm{TCR}$ and $\gamma \delta \mathrm{T}$ cells were both rheumatologists, a profession which focuses on ARDs [4,5]. It is therefore gratifying to note from the comprehensive data presented above, that while $\gamma \delta \mathrm{T}$ cells are a highly conserved subset of T cells of basic importance to all aspects of immunobiology, the role of these cells in ARDs, in particular, cannot be ignored. Thus, we have shown that ARDs are associated with quantitative and qualitative perturbations of the systemic and localized distribution of specific $\gamma \delta$ TCR and of the functional programs of the cells expressing these receptors. These, in turn, may have profound effects on the development, manifestations, and outcome of ARDs. Animal models suggest that $\gamma \delta$ T cells exert their influence via modulatory effects on classical auto-antigen reactive $\alpha \beta$ T cells and B cells-central mediators of ARDs. However, they also playing an independent effector pro-inflammatory role, mediated by their innate ability to secrete IL-17, TNF $\alpha$, and IFN $\gamma$ in a non- antigen driven fashion. Looming above all this is a crucial, largely unanswered central question: what are the specific auto-antigens for $\gamma \delta$ TCR in ARDs? Likewise, what is the role of and how are putative antigen presenting molecules such as CD1d, MR1, and butyrophilins involved? Future studies will likely address these questions and the answers will likely lead to a novel and deeper understanding of ARDs and ways to treat them, for the benefit of patients suffering from these chronic diseases. 
Funding: This research received no external funding.

Conflicts of Interest: The authors declare no conflict of interest.

\section{References}

1. Allison, J.P.; Ridge, L.; Lund, J.; Gross-Pelose, J.; Lanier, L.; McIntyre, B.W. The murine T cell antigen receptor and associated structures. Immunol. Rev. 1984, 81, 145-160. [CrossRef] [PubMed]

2. Acuto, O.; Hussey, R.E.; Fitzgerald, K.A.; Protentis, J.P.; Meuer, S.C.; Schlossman, S.F.; Reinherz, E.L. The human T cell receptor: Appearance in ontogeny and biochemical relationship of alpha and beta subunits on IL-2 dependent clones and T cell tumors. Cell 1983, 34, 717-726. [CrossRef]

3. Saito, H.; Kranz, D.M.; Takagaki, Y.; Hayday, A.C.; Eisen, H.N.; Tonegawa, S. A third rearranged and expressed gene in a clone of cytotoxic T lymphocytes. Nature 1984, 312, 36-40. [CrossRef] [PubMed]

4. Bank, I.; DePinho, R.A.; Brenner, M.B.; Cassimeris, J.; Alt, F.W.; Chess, L. A functional T3 molecule associated with a novel heterodimer on the surface of immature human thymocytes. Nature 1986, 322, 179-181. [CrossRef]

5. Brenner, M.B.; McLean, J.; Dialynas, D.P.; Strominger, J.L.; Smith, J.A.; Owen, F.L.; Seidman, J.G.; Ip, S.; Rosen, F.; Krangel, M.S. Identification of a putative second T-cell receptor. Nature 1986, 322, 145-149. [CrossRef]

6. Chien, Y.H.; Iwashima, M.; Kaplan, K.B.; Elliott, J.F.; Davis, M.M. A new T-cell receptor gene located within the alpha locus and expressed early in T-cell differentiation. Nature 1987, 327, 677-682. [CrossRef]

7. Vermijlen, D.; Gatti, D.; Kouzeli, A.; Rus, T.; Eberl, M. gammadelta T cell responses: How many ligands will it take till we know? Semin Cell Dev. Biol. 2018, 84, 75-86. [CrossRef]

8. Yang, Y.; Li, L.; Yuan, L.; Zhou, X.; Duan, J.; Xiao, H.; Cai, N.; Han, S.; Ma, X.; Liu, W.; et al. A Structural Change in Butyrophilin upon Phosphoantigen Binding Underlies Phosphoantigen-Mediated V $\gamma 9$ V 82 T Cell Activation. Immunity 2019, 50, 1043.e5-1053.e5. [CrossRef]

9. Melandri, D.; Zlatareva, I.; Chaleil, R.A.G.; Dart, R.J.; Chancellor, A.; Nussbaumer, O.; Polyakova, O.; Roberts, N.A.; Wesch, D.; Kabelitz, D.; et al. The $\gamma \delta$ TCR combines innate immunity with adaptive immunity by utilizing spatially distinct regions for agonist selection and antigen responsiveness. Nat. Immunol. 2018, 19, 1352-1365. [CrossRef]

10. Adams, E.J.; Gu, S.; Luoma, A.M. Human gamma delta T cells: Evolution and ligand recognition. Cell Immunol. 2015, 296, 31-40. [CrossRef]

11. Hayday, A.C. gammadelta T Cell Update: Adaptate Orchestrators of Immune Surveillance. J. Immunol. 2019, 203, 311-320. [CrossRef] [PubMed]

12. Vantourout, P.; Hayday, A. Six-of-the-best: Unique contributions of gammadelta T cells to immunology. Nat. Rev. Immunol. 2013, 13, 88-100. [CrossRef] [PubMed]

13. Papotto, P.H.; Reinhardt, A.; Prinz, I.; Silva-Santos, B. Innately versatile: gammadelta17 T cells in inflammatory and autoimmune diseases. J. Autoimmun. 2018, 87, 26-37. [CrossRef] [PubMed]

14. Chien, Y.H.; Meyer, C.; Bonneville, M. gammadelta T cells: First line of defense and beyond. Annu Rev. Immunol. 2014, 32, 121-155. [CrossRef]

15. Bank, I.; Marcu-Malina, V. Quantitative peripheral blood perturbations of $\gamma \delta \mathrm{T}$ cells in human disease and their clinical implications. Clin. Rev. Allergy Immunol. 2014, 47, 311-333. [CrossRef]

16. Silva-Santos, B.; Mensurado, S.; Coffelt, S.B. gammadelta T cells: Pleiotropic immune effectors with therapeutic potential in cancer. Nat. Rev. Cancer 2019, 19, 392-404. [CrossRef]

17. Rudan, I.; Sidhu, S.; Papana, A.; Meng, S.J.; Yu, X.-W.; Wang, W.; Campbell-Page, R.M.; Demaio, A.R.; Nair, H.; Sridhar, D.; et al. Prevalence of rheumatoid arthritis in low- and middle-income countries: A systematic review and analysis. J. Glob. Health 2015, 5, 010409. [CrossRef]

18. Liu, M.F.; Yang, C.Y.; Chao, S.C.; Li, J.S.; Weng, T.H.; Lei, H.Y. Distribution of double-negative (CD4- CD8-, DN) T subsets in blood and synovial fluid from patients with rheumatoid arthritis. Clin. Rheumatol. 1999, 18, 227-231. [CrossRef]

19. Gaur, P.; Misra, R.; Aggarwal, A. Natural killer cell and gamma delta T cell alterations in enthesitis related arthritis category of juvenile idiopathic arthritis. Clin. Immunol. 2015, 161, 163-169. [CrossRef]

20. Hassan, J.; Feighery, C.; Bresnihan, B.; Whelan, A. Effect of gold therapy on CD5+ B-cells and TCR gamma delta+ T-cells in patients with rheumatoid arthritis. Rheumatol. Int. 1991, 11, 175-178. [CrossRef] 
21. Abuzakouk, M.; Feighery, C.; Kelleher, D.; O’Briain, D.S.; Jones, E.; Weir, D.; Casey, E.; O’Farrelly, C. Increased HLA-DR and CD44 antigen expression in the gut: Evidence of extraarticular immunological activity in rheumatoid arthritis. J. Rheumatol. 1999, 26, 1869-1876.

22. Mitogawa, T.; Nishiya, K.; Ota, Z. Frequency of gamma delta T cells in peripheral blood, synovial fluid, synovial membrane and lungs from patients with rheumatoid arthritis. Acta. Med. Okayama 1992, 46, 371-379. [CrossRef] [PubMed]

23. Brennan, F.; Plater-Zyberk, C.; Maini, R.N.; Feldmann, M. Coordinate expansion of 'fetal type' lymphocytes (TCR gamma delta+T and CD5+B) in rheumatoid arthritis and primary Sjogren's syndrome. Clin. Exp. Immunol. 1989, 77, 175-178. [PubMed]

24. Hu, C.; Qian, L.; Miao, Y.; Huang, Q.; Miao, P.; Wang, P.; Yu, Q.; Nie, H.; Zhang, J.; He, D.; et al. Antigen-presenting effects of effector memory Vgamma9Vdelta2 T cells in rheumatoid arthritis. Cell Mol. Immunol. 2012, 9, 245-254. [CrossRef] [PubMed]

25. Guggino, G.; Orlando, V.; Saieva, L.; Ruscitti, P.; Cipriani, P.; La Manna, M.P.; Giacomelli, R.; Alessandro, R.; Triolo, G.; Ciccia, F.; et al. Downregulation of miRNA17-92 cluster marks Vgamma9Vdelta2 T cells from patients with rheumatoid arthritis. Arthritis. Res. Ther. 2018, 20, 236. [CrossRef] [PubMed]

26. Su, D.; Shen, M.; Gu, B.; Wang, X.; Wang, D.; Li, X.; Sun, L. (99) Tc-methylene diphosphonate improves rheumatoid arthritis disease activity by increasing the frequency of peripheral gammadelta $\mathrm{T}$ cells and CD4(+) CD25(+) Foxp3(+) Tregs. Int. J. Rheum. Dis. 2016, 19, 586-593. [CrossRef]

27. Mo, W.X.; Yin, S.S.; Chen, H.; Zhou, C.; Zhou, J.X.; Zhao, L.D.; Fei, Y.Y.; Yang, H.X.; Guo, J.B.; Mao, Y.J.; et al. Chemotaxis of Vdelta2 $\mathrm{T}$ cells to the joints contributes to the pathogenesis of rheumatoid arthritis. Ann. Rheum. Dis. 2017, 76, 2075-2084. [CrossRef]

28. Lamour, A.; Jouen-Beades, F.; Lees, O.; Gilbert, D.; Le Loet, X.; Tron, F. Analysis of T cell receptors in rheumatoid arthritis: The increased expression of HLA-DR antigen on circulating gamma delta+ T cells is correlated with disease activity. Clin. Exp. Immunol. 1992, 89, 217-222. [CrossRef]

29. Schwaneck, E.C.; Renner, R.; Junker, L.; Einsele, H.; Gadeholt, O.; Geissinger, E.; Kleinert, S.; Gernert, M.; Tony, H.P.; Schmalzing, M. Prevalence and Characteristics of Persistent Clonal T Cell Large Granular Lymphocyte Expansions in Rheumatoid Arthritis: A Comprehensive Analysis of 529 Patients. Okayama Rheumatol. 2018, 70, 1914-1922. [CrossRef]

30. Yabe, M.; Medeiros, L.J.; Wang, S.A.; Konoplev, S.; Ok, C.Y.; Loghavi, S.; Lu, G.; Flores, L.; Khoury, J.D.; Cason, R.C.; et al. Clinicopathologic, Immunophenotypic, Cytogenetic, and Molecular Features of gammadelta T-Cell Large Granular Lymphocytic Leukemia: An Analysis of 14 Patients Suggests Biologic Differences With alphabeta T-Cell Large Granular Lymphocytic Leukemia. [corrected]. Am. J. Clin. Pathol. 2015, 144, 607-619. [CrossRef]

31. Bourgault-Rouxel, A.S.; Loughran, T.P., Jr.; Zambello, R.; Epling-Burnette, P.K.; Semenzato, G.; Donadieu, J.; Amiot, L.; Fest, T.; Lamy, T. Clinical spectrum of gammadelta+ T cell LGL leukemia: Analysis of 20 cases. Leuk. Res. 2008, 32, 45-48. [CrossRef] [PubMed]

32. Jacobs, M.R.; Haynes, B.F. Increase in TCR gamma delta T lymphocytes in synovia from rheumatoid arthritis patients with active synovitis. J. Clin. Immunol. 1992, 12, 130-138. [CrossRef] [PubMed]

33. el-Gabalawy, H.S.; Keillor, J. Immunohistologic study of T-cell receptor delta-chain expression in rheumatoid synovial membranes. Semin. Arthritis Rheumatol. 1992, 21, 239-245. [CrossRef]

34. Bodman-Smith, M.D.; Anand, A.; Durand, V.; Youinou, P.Y.; Lydyard, P.M. Decreased expression of FcgammaRIII (CD16) by gammadelta T cells in patients with rheumatoid arthritis. Immunology 2000, 99, 498-503. [CrossRef]

35. Andreu, J.L.; Trujillo, A.; Alonso, J.M.; Mulero, J.; Martinez, C. Selective expansion of T cells bearing the gamma/delta receptor and expressing an unusual repertoire in the synovial membrane of patients with rheumatoid arthritis. Arthritis Rheumatol. 1991, 34, 808-814. [CrossRef]

36. Soderstrom, K.; Bucht, A.; Halapi, E.; Lundqvist, C.; Gronberg, A.; Nilsson, E.; Orsini, D.L.; van de Wal, Y.; Koning, F.; Hammarstrom, M.L.; et al. High expression of V gamma 8 is a shared feature of human gamma delta T cells in the epithelium of the gut and in the inflamed synovial tissue. J. Immunol. 1994, 152, 6017-6027.

37. Kageyama, Y.; Koide, Y.; Miyamoto, S.; Inoue, T.; Yoshida, T.O. The biased V gamma gene usage in the synovial fluid of patients with rheumatoid arthritis. Eur. J. Immunol. 1994, 24, 1122-1129. [CrossRef] 
38. Olive, C.; Gatenby, P.A.; Serjeantson, S.W. Variable gene usage of T cell receptor gamma- and delta-chain transcripts expressed in synovia and peripheral blood of patients with rheumatoid arthritis. Clin. Exp. Immunol. 1992, 87, 172-177. [CrossRef]

39. Doherty, P.J.; Inman, R.D.; Laxer, R.M.; Silverman, E.D.; Yang, S.X.; Suurmann, I.; Pan, S. Analysis of T cell receptor gamma transcripts in right and left knee synovial fluids of patients with rheumatoid arthritis. J. Rheumatol. 1996, 23, 1143-1150.

40. Olive, C.; Gatenby, P.A.; Serjeantson, S.W. Evidence for oligoclonality of T cell receptor delta chain transcripts expressed in rheumatoid arthritis patients. Eur. J. Immunol. 1992, 22, 2587-2593. [CrossRef]

41. Le Nours, J.; Gherardin, N.A.; Ramarathinam, S.H.; Awad, W.; Wiede, F.; Gully, B.S.; Khandokar, Y.; Praveena, T.; Wubben, J.M.; Sandow, J.J.; et al. A class of gammadelta T cell receptors recognize the underside of the antigen-presenting molecule MR1. Science 2019, 366, 1522-1527. [CrossRef] [PubMed]

42. Chomarat, P.; Kjeldsen-Kragh, J.; Quayle, A.J.; Natvig, J.B.; Miossec, P. Different cytokine production profiles of gamma delta T cell clones: Relation to inflammatory arthritis. Eur. J. Immunol. 1994, 24, 2087-2091. [CrossRef] [PubMed]

43. Bank, I.; Tanay, A.; Migdal, A.; Book, M.; Livneh, A. V gamma 9-V delta 2+ gamma delta T cells from a patient with Felty syndrome that exhibit aberrant response to triggering of the CD3 molecule can regulate immunoglobulin secretion by B cells. Clin. Immunol. Immunopathol. 1995, 74, 162-169. [CrossRef] [PubMed]

44. Pollinger, B.; Junt, T.; Metzler, B.; Walker, U.A.; Tyndall, A.; Allard, C.; Bay, S.; Keller, R.; Raulf, F.; Di Padova, F.; et al. Th17 cells, not IL-17+ gammadelta T cells, drive arthritic bone destruction in mice and humans. J. Immunol. 2011, 186, 2602-2612. [CrossRef]

45. Tanaka, Y.; Sano, S.; Nieves, E.; De Libero, G.; Rosa, D.; Modlin, R.L.; Brenner, M.B.; Bloom, B.R.; Morita, C.T. Nonpeptide ligands for human gamma delta T cells. Proc. Natl. Acad. Sci. USA 1994, 91, 8175-8179. [CrossRef]

46. Laurent, A.J.; Bindslev, N.; Johansson, B.; Berg, L. Synergistic effects of ethanol and isopentenyl pyrophosphate on expansion of gammadelta T cells in synovial fluid from patients with arthritis. PLoS ONE 2014, 9, e103683. [CrossRef]

47. Li, N.L.; Zhang, D.Q.; Zhou, K.Y.; Cartman, A.; Leroux, J.Y.; Poole, A.R.; Zhang, Y.P. Isolation and characteristics of autoreactive $\mathrm{T}$ cells specific to aggrecan $\mathrm{G} 1$ domain from rheumatoid arthritis patients. Cell Res. 2000, 10, 39-49. [CrossRef] [PubMed]

48. Ohta, M.; Sato, N. The cytotoxic analysis of $\mathrm{T}$ cell receptor V delta $1+\mathrm{T}$ cell lines derived from the synovial fluid of rheumatoid arthritis patients. Clin. Exp. Immunol. 1994, 97, 193-199. [CrossRef]

49. Kogure, A.; Miyata, M.; Nishimaki, T.; Kasukawa, R. Proliferative response of synovial fluid mononuclear cells of patients with rheumatoid arthritis to mycobacterial $65 \mathrm{kDa}$ heat shock protein and its association with HLA-DR+.gamma delta+ T cells. J. Rheumatol. 1994, 21, 1403-1408.

50. Holoshitz, J.; Vila, L.M.; Keroack, B.J.; McKinley, D.R.; Bayne, N.K. Dual antigenic recognition by cloned human gamma delta T cells. J. Clin. Invest. 1992, 89, 308-314. [CrossRef]

51. Bank, I.; Cohen, L.; Mouallem, M.; Farfel, Z.; Grossman, E.; Ben-Nun, A. gammadelta T cell subsets in patients with arthritis and chronic neutropenia. Ann. Rheum. Dis. 2002, 61, 438-443. [CrossRef] [PubMed]

52. Pelegri, C.; Kuhnlein, P.; Buchner, E.; Schmidt, C.B.; Franch, A.; Castell, M.; Hunig, T.; Emmrich, F.; Kinne, R.W. Depletion of gamma/delta $\mathrm{T}$ cells does not prevent or ameliorate, but rather aggravates, rat adjuvant arthritis. Arthritis Rheumatol. 1996, 39, 204-215. [CrossRef] [PubMed]

53. Yoshino, S.; Schlipkoter, E.; Kinne, R.; Hunig, T.; Emmrich, F. Suppression and prevention of adjuvant arthritis in rats by a monoclonal antibody to the alpha/beta T cell receptor. Eur. J. Immunol. 1990, 20, 2805-2808. [CrossRef] [PubMed]

54. Jansson, A.M.; Lorentzen, J.C.; Bucht, A. CD8+ cells suppress oil-induced arthritis. Clin. Exp. Immunol. 2000, 120, 532-536. [CrossRef]

55. Carlson, B.C.; Jansson, A.M.; Larsson, A.; Bucht, A.; Lorentzen, J.C. The endogenous adjuvant squalene can induce a chronic T-cell-mediated arthritis in rats. Am. J. Pathol. 2000, 156, 2057-2065. [CrossRef]

56. Corthay, A.; Johansson, A.; Vestberg, M.; Holmdahl, R. Collagen-induced arthritis development requires alpha beta T cells but not gamma delta T cells: Studies with T cell-deficient (TCR mutant) mice. Int. Immunol. 1999, 11, 1065-1073. [CrossRef]

57. Arai, K.; Yamamura, S.; Hanyu, T.; Takahashi, H.E.; Umezu, H.; Watanabe, H.; Abo, T. Extrathymic differentiation of resident $\mathrm{T}$ cells in the joints of mice with collagen-induced arthritis. J. Immunol. 1996, 157, 5170-5177. 
58. Roark, C.L.; French, J.D.; Taylor, M.A.; Bendele, A.M.; Born, W.K.; O’Brien, R.L. Exacerbation of collagen-induced arthritis by oligoclonal, IL-17-producing gamma delta T cells. J. Immunol. 2007, 179, 5576-5583. [CrossRef]

59. Cornelissen, F.; Mus, A.M.; Asmawidjaja, P.S.; van Hamburg, J.P.; Tocker, J.; Lubberts, E. Interleukin-23 is critical for full-blown expression of a non-autoimmune destructive arthritis and regulates interleukin-17A and RORgammat in gammadelta T cells. Arthritis. Res. Ther. 2009, 11, R194. [CrossRef]

60. Xue, X.; Soroosh, P.; De Leon-Tabaldo, A.; Luna-Roman, R.; Sablad, M.; Rozenkrants, N.; Yu, J.; Castro, G.; Banie, H.; Fung-Leung, W.P.; et al. Pharmacologic modulation of RORgammat translates to efficacy in preclinical and translational models of psoriasis and inflammatory arthritis. Sci. Rep. 2016, 6, 37977. [CrossRef]

61. Blazek, K.; Eames, H.L.; Weiss, M.; Byrne, A.J.; Perocheau, D.; Pease, J.E.; Doyle, S.; McCann, F.; Williams, R.O.; Udalova, I.A. IFN-lambda resolves inflammation via suppression of neutrophil infiltration and IL-1beta production. J. Exp. Med. 2015, 212, 845-853. [CrossRef] [PubMed]

62. Harnett, M.M.; Harnett, W.; Pineda, M.A. The parasitic worm product ES-62 up-regulates IL-22 production by gammadelta T cells in the murine model of Collagen-Induced Arthritis. Inflamm. Cell Signal. 2014, 1. [CrossRef]

63. Pineda, M.A.; McGrath, M.A.; Smith, P.C.; Al-Riyami, L.; Rzepecka, J.; Gracie, J.A.; Harnett, W.; Harnett, M.M. The parasitic helminth product ES-62 suppresses pathogenesis in collagen-induced arthritis by targeting the interleukin-17-producing cellular network at multiple sites. Arthritis Rheumatol. 2012, 64, 3168-3178. [CrossRef] [PubMed]

64. Tao, J.; Kamanaka, M.; Hao, J.; Hao, Z.; Jiang, X.; Craft, J.E.; Flavell, R.A.; Wu, Z.; Hong, Z.; Zhao, L.; et al. IL-10 signaling in CD4+ T cells is critical for the pathogenesis of collagen-induced arthritis. Arthritis. Res. Ther. 2011, 13, R212. [CrossRef]

65. Ito, Y.; Usui, T.; Kobayashi, S.; Iguchi-Hashimoto, M.; Ito, H.; Yoshitomi, H.; Nakamura, T.; Shimizu, M.; Kawabata, D.; Yukawa, N.; et al. Gamma/delta T cells are the predominant source of interleukin-17 in affected joints in collagen-induced arthritis, but not in rheumatoid arthritis. Arthritis Rheumatol. 2009, 60, 2294-2303. [CrossRef]

66. Evans-Marin, H.; Rogier, R.; Koralov, S.B.; Manasson, J.; Roeleveld, D.; van der Kraan, P.M.; Scher, J.U.; Koenders, M.I.; Abdollahi-Roodsaz, S. Microbiota-Dependent Involvement of Th17 Cells in Murine Models of Inflammatory Arthritis. Arthritis. Rheumatol. 2018, 70, 1971-1983. [CrossRef]

67. Bouchareychas, L.; Grossinger, E.M.; Kang, M.; Adamopoulos, I.E. gammadeltaTCR regulates production of interleukin-27 by neutrophils and attenuates inflammatory arthritis. Sci. Rep. 2018, 8, 7590. [CrossRef]

68. Akitsu, A.; Ishigame, H.; Kakuta, S.; Chung, S.H.; Ikeda, S.; Shimizu, K.; Kubo, S.; Liu, Y.; Umemura, M.; Matsuzaki, G.; et al. IL-1 receptor antagonist-deficient mice develop autoimmune arthritis due to intrinsic activation of IL-17-producing CCR2(+)Vgamma6(+)gammadelta T cells. Nat. Commun. 2015, 6, 7464. [CrossRef]

69. Noto Llana, M.; Sarnacki, S.H.; Morales, A.L.; Aya Castaneda, M.D.R.; Giacomodonato, M.N.; Blanco, G.; Cerquetti, M.C. Activation of iNKT Cells Prevents Salmonella-Enterocolitis and Salmonella-Induced Reactive Arthritis by Downregulating IL-17-Producing gammadeltaT Cells. Front. Cell Infect. Microbiol. 2017, 7, 398. [CrossRef]

70. Khmaladze, I.; Kelkka, T.; Guerard, S.; Wing, K.; Pizzolla, A.; Saxena, A.; Lundqvist, K.; Holmdahl, M.; Nandakumar, K.S.; Holmdahl, R. Mannan induces ROS-regulated, IL-17A-dependent psoriasis arthritis-like disease in mice. Proc. Natl. Acad. Sci. USA 2014, 111, E3669-E3678. [CrossRef]

71. Massa, M.; de Benedetti, F.; Robbioni, P.; Ramenghi, B.; Albani, S.; Martini, A. Association of methotrexate treatment with a decrease of double negative (CD4-CD8-) and gamma/delta T cell levels in patients with juvenile rheumatoid arthritis. J. Rheumatol. 1993, 20, 1944-1948. [PubMed]

72. Rosser, E.C.; Lom, H.; Bending, D.; Duurland, C.L.; Bajaj-Elliott, M.; Wedderburn, L.R. Innate Lymphoid Cells and T Cells Contribute to the Interleukin-17A Signature Detected in the Synovial Fluid of Patients With Juvenile Idiopathic Arthritis. Arthritis. Rheumatol. 2019, 71, 460-467. [CrossRef] [PubMed]

73. Macaubas, C.; Nguyen, K.; Deshpande, C.; Phillips, C.; Peck, A.; Lee, T.; Park, J.L.; Sandborg, C.; Mellins, E.D. Distribution of circulating cells in systemic juvenile idiopathic arthritis across disease activity states. Clin. Immunol. 2010, 134, 206-216. [CrossRef] [PubMed]

74. Licciardi, F.; Ceci, M.; Toppino, C.; Turco, M.; Martino, S.; Ricotti, E.; Ferro, F.; Montin, D. Low synovial double negative $\mathrm{T}$ and gammadelta $\mathrm{T}$ cells predict longer free-disease survival in oligoarticular JIA. Cytometry $B$ Clin. Cytom. 2018, 94, 423-427. [CrossRef] 
75. Kjeldsen-Kragh, J.; Quayle, A.J.; Vinje, O.; Natvig, J.B.; Forre, O. A high proportion of the V delta 1+ synovial fluid gamma delta $\mathrm{T}$ cells in juvenile rheumatoid arthritis patients express the very early activation marker CD69, but carry the high molecular weight isoform of the leucocyte common antigen (CD45RA). Clin. Exp. Immunol. 1993, 91, 202-206. [CrossRef]

76. Berkun, Y.; Bendersky, A.; Gerstein, M.; Goldstein, I.; Padeh, S.; Bank, I. GammadeltaT cells in juvenile idiopathic arthritis: Higher percentages of synovial Vdelta1+ and Vgamma9+ T cell subsets are associated with milder disease. J. Rheumatol. 2011, 38, 1123-1129. [CrossRef]

77. Kessel, C.; Lippitz, K.; Weinhage, T.; Hinze, C.; Wittkowski, H.; Holzinger, D.; Fall, N.; Grom, A.A.; Gruen, N.; Foell, D. Proinflammatory Cytokine Environments Can Drive Interleukin-17 Overexpression by gamma/delta T Cells in Systemic Juvenile Idiopathic Arthritis. Arthritis. Rheumatol. 2017, 69, 1480-1494. [CrossRef]

78. Bendersky, A.; Marcu-Malina, V.; Berkun, Y.; Gerstein, M.; Nagar, M.; Goldstein, I.; Padeh, S.; Bank, I. Cellular interactions of synovial fluid gammadelta T cells in juvenile idiopathic arthritis. J. Immunol. 2012, 188, 4349-4359. [CrossRef]

79. Avau, A.; Mitera, T.; Put, S.; Put, K.; Brisse, E.; Filtjens, J.; Uyttenhove, C.; Van Snick, J.; Liston, A.; Leclercq, G.; et al. Systemic juvenile idiopathic arthritis-like syndrome in mice following stimulation of the immune system with Freund's complete adjuvant: Regulation by interferon-gamma. Arthritis. Rheumatol. 2014, 66, 1340-1351. [CrossRef]

80. Kenna, T.J.; Davidson, S.I.; Duan, R.; Bradbury, L.A.; McFarlane, J.; Smith, M.; Weedon, H.; Street, S.; Thomas, R.; Thomas, G.P.; et al. Enrichment of circulating interleukin-17-secreting interleukin-23 receptor-positive gamma/delta $\mathrm{T}$ cells in patients with active ankylosing spondylitis. Arthritis Rheum. 2012, 64, 1420-1429. [CrossRef]

81. Venken, K.; Jacques, P.; Mortier, C.; Labadia, M.E.; Decruy, T.; Coudenys, J.; Hoyt, K.; Wayne, A.L.; Hughes, R.; Turner, M.; et al. RORgammat inhibition selectively targets IL-17 producing iNKT and gammadelta-T cells enriched in Spondyloarthritis patients. Nat. Commun. 2019, 10, 9. [CrossRef]

82. Al-Mossawi, M.H.; Chen, L.; Fang, H.; Ridley, A.; de Wit, J.; Yager, N.; Hammitzsch, A.; Pulyakhina, I.; Fairfax, B.P.; Simone, D.; et al. Unique transcriptome signatures and GM-CSF expression in lymphocytes from patients with spondyloarthritis. Nat. Commun. 2017, 8, 1510. [CrossRef]

83. Toussirot, E.; Laheurte, C.; Gaugler, B.; Gabriel, D.; Saas, P. Increased IL-22- and IL-17A-Producing Mucosal-Associated Invariant T Cells in the Peripheral Blood of Patients With Ankylosing Spondylitis. Front. Immunol. 2018, 9, 1610. [CrossRef] [PubMed]

84. Gracey, E.; Qaiyum, Z.; Kuruvilla, J.; Inman, R.D. Gamma Delta T Cell Subset V Gamma 2+ Expansion Associated with Longterm Infliximab Treatment in a Patient with Ankylosing Spondylitis. J. Rheumatol. 2016, 43, 2079-2082. [CrossRef] [PubMed]

85. Hermann, E.; Ackermann, B.; Duchmann, R.; Meyer zum Buschenfelde, K.H. Synovial fluid MHC-unrestricted gamma delta-T lymphocytes contribute to antibacterial and anti-self cytotoxicity in the spondylarthropathies. Clin. Exp. Rheumatol. 1995, 13, 187-191. [PubMed]

86. Reinhardt, A.; Yevsa, T.; Worbs, T.; Lienenklaus, S.; Sandrock, I.; Oberdorfer, L.; Korn, T.; Weiss, S.; Forster, R.; Prinz, I. Interleukin-23-Dependent gamma/delta T Cells Produce Interleukin-17 and Accumulate in the Enthesis, Aortic Valve, and Ciliary Body in Mice. Arthritis Rheumatol. 2016, 68, 2476-2486. [CrossRef]

87. Wang, L.; Kang, N.; Zhou, J.; Guo, Y.; Zhang, X.; Cui, L.; Ba, D.; He, W. Downregulation of CD94/NKG2A inhibitory receptor on decreased gammadelta $\mathrm{T}$ cells in patients with systemic lupus erythematosus. Scand. J. Immunol. 2012, 76, 62-69. [CrossRef]

88. Ma, H.; Yuan, Y.; Zhao, L.; Ye, Z.; Xu, J.; Li, M.; Jiang, Z.; Jiang, Y. Association of gammadelta T Cell Compartment Size to Disease Activity and Response to Therapy in SLE. PLoS ONE 2016, 11, e0157772. [CrossRef]

89. Li, X.; Kang, N.; Zhang, X.; Dong, X.; Wei, W.; Cui, L.; Ba, D.; He, W. Generation of human regulatory gammadelta $\mathrm{T}$ cells by TCRgammadelta stimulation in the presence of TGF-beta and their involvement in the pathogenesis of systemic lupus erythematosus. J. Immunol. 2011, 186, 6693-6700. [CrossRef]

90. Robak, E.; Niewiadomska, H.; Robak, T.; Bartkowiak, J.; Blonski, J.Z.; Wozniacka, A.; Pomorski, L.; Sysa-Jedrezejowska, A. Lymphocyctes Tgammadelta in clinically normal skin and peripheral blood of patients with systemic lupus erythematosus and their correlation with disease activity. Mediators. Inflamm. 2001, 10, 179-189. [CrossRef] 
91. Holcombe, R.F.; Baethge, B.A.; Wolf, R.E.; Betzing, K.W.; Stewart, R.M. Natural killer cells and gamma delta T cells in scleroderma: Relationship to disease duration and anti-Scl-70 antibodies. Ann. Rheum. Dis. 1995, 54, 69-72. [CrossRef] [PubMed]

92. Rajagopalan, S.; Zordan, T.; Tsokos, G.C.; Datta, S.K. Pathogenic anti-DNA autoantibody-inducing T helper cell lines from patients with active lupus nephritis: Isolation of CD4-8- T helper cell lines that express the gamma delta T-cell antigen receptor. Proc. Natl. Acad. Sci. USA 1990, 87, 7020-7024. [CrossRef] [PubMed]

93. Samuelson, E.M.; Laird, R.M.; Papillion, A.M.; Tatum, A.H.; Princiotta, M.F.; Hayes, S.M. Reduced B lymphoid kinase (Blk) expression enhances proinflammatory cytokine production and induces nephrosis in C57BL/6-lpr/lpr mice. PLoS ONE 2014, 9, e92054. [CrossRef] [PubMed]

94. Page, N.; Schall, N.; Strub, J.M.; Quinternet, M.; Chaloin, O.; Decossas, M.; Cung, M.T.; Van Dorsselaer, A.; Briand, J.P.; Muller, S. The spliceosomal phosphopeptide P140 controls the lupus disease by interacting with the HSC70 protein and via a mechanism mediated by gammadelta T cells. PLoS ONE 2009, 4, e5273. [CrossRef]

95. Giacomelli, R.; Matucci-Cerinic, M.; Cipriani, P.; Ghersetich, I.; Lattanzio, R.; Pavan, A.; Pignone, A.; Cagnoni, M.L.; Lotti, T.; Tonietti, G. Circulating Vdelta1+ T cells are activated and accumulate in the skin of systemic sclerosis patients. Arthritis Rheumatol. 1998, 41, 327-334. [CrossRef]

96. Wood, G.M.; Dawisha, S.; Gourley, M. Characteristics of HPRT-mutant T cell lines in a lupus patient treated with cyclophosphamide. Arthritis Rheumatol. 1994, 37, 1548-1552. [CrossRef]

97. Peng, S.L.; Madaio, M.P.; Hayday, A.C.; Craft, J. Propagation and regulation of systemic autoimmunity by gammadelta T cells. J. Immunol. 1996, 157, 5689-5698.

98. Qiu, F.; Li, T.; Zhang, K.; Wan, J.; Qi, X. CD4(+)B220(+)TCRgammadelta(+) T cells produce IL-17 in lupus-prone MRL/lpr mice. Int. Immunopharmacol. 2016, 38, 31-39. [CrossRef]

99. Jacinto, J.; Kim, P.J.; Singh, R.R. Disparate effects of depletion of CD1d-reactive T cells during early versus late stages of disease in a genetically susceptible model of lupus. Lupus 2012, 21, 485-490. [CrossRef]

100. Rezende, R.M.; Lanser, A.J.; Rubino, S.; Kuhn, C.; Skillin, N.; Moreira, T.G.; Liu, S.; Gabriely, G.; David, B.A.; Menezes, G.B.; et al. gammadelta T cells control humoral immune response by inducing $\mathrm{T}$ follicular helper cell differentiation. Nat. Commun. 2018, 9, 3151. [CrossRef]

101. Riedel, J.H.; Paust, H.J.; Krohn, S.; Turner, J.E.; Kluger, M.A.; Steinmetz, O.M.; Krebs, C.F.; Stahl, R.A.; Panzer, U. IL-17F Promotes Tissue Injury in Autoimmune Kidney Diseases. J. Am. Soc. Nephrol. 2016, 27, 3666-3677. [CrossRef] [PubMed]

102. Riccieri, V.; Parisi, G.; Spadaro, A.; Scrivo, R.; Barone, F.; Moretti, T.; Bernardini, G.; Strom, R.; Taccari, E.; Valesini, G. Reduced circulating natural killer T cells and gamma/delta $\mathrm{T}$ cells in patients with systemic sclerosis. J. Rheumatol. 2005, 32, 283-286. [PubMed]

103. Bendersky, A.; Markovits, N.; Bank, I. Vgamma9+ gammadelta T cells in systemic sclerosis patients are numerically and functionally preserved and induce fibroblast apoptosis. Immunobiology 2010, 215, 380-394. [CrossRef]

104. Segawa, S.; Goto, D.; Horikoshi, M.; Kondo, Y.; Umeda, N.; Hagiwara, S.; Yokosawa, M.; Hirota, T.; Miki, H.; Tsuboi, H.; et al. Involvement of CD161+ Vdelta1+ gammadelta T cells in systemic sclerosis: Association with interstitial pneumonia. Rheumatology 2014, 53, 2259-2269. [CrossRef] [PubMed]

105. Ueda-Hayakawa, I.; Hasegawa, M.; Hamaguchi, Y.; Takehara, K.; Fujimoto, M. Circulating gamma/delta T cells in systemic sclerosis exhibit activated phenotype and enhance gene expression of proalpha2(I) collagen of fibroblasts. J. Dermatol. Sci. 2013, 69, 54-60. [CrossRef]

106. Henriques, A.; Silva, C.; Santiago, M.; Henriques, M.J.; Martinho, A.; Trindade, H.; da Silva, J.A.; Silva-Santos, B.; Paiva, A. Subset-specific alterations in frequencies and functional signatures of gammadelta T cells in systemic sclerosis patients. Inflamm. Res. 2016, 65, 985-994. [CrossRef]

107. Kahaleh, M.B.; Fan, P.S.; Otsuka, T. Gammadelta receptor bearing T cells in scleroderma: Enhanced interaction with vascular endothelial cells in vitro. Clin. Immunol. 1999, 91, 188-195. [CrossRef]

108. Yurovsky, V.V.; Sutton, P.A.; Schulze, D.H.; Wigley, F.M.; Wise, R.A.; Howard, R.F.; White, B. Expansion of selected V delta 1+ gamma delta T cells in systemic sclerosis patients. J. Immunol. 1994, 153, 881-891.

109. Migalovich Sheikhet, H.; Villacorta Hidalgo, J.; Fisch, P.; Balbir-Gurman, A.; Braun-Moscovici, Y.; Bank, I. Dysregulated CD25 and Cytokine Expression by gammadelta T Cells of Systemic Sclerosis Patients Stimulated With Cardiolipin and Zoledronate. Front. Immunol. 2018, 9, 753. [CrossRef]

110. Marcu-Malina, V.; Balbir-Gurman, A.; Dardik, R.; Braun-Moscovici, Y.; Segel, M.J.; Bank, I. A Novel Prothrombotic Pathway in Systemic Sclerosis Patients: Possible Role of Bisphosphonate-Activated gammadelta T Cells. Front. Immunol. 2014, 5, 414. [CrossRef] 
111. Markovits, N.; Bendersky, A.; Loebstein, R.; Brusel, M.; Kessler, E.; Bank, I. Anti-fibrotic characteristics of Vgamma9+ gammadelta T cells in systemic sclerosis. Clin. Exp. Rheumatol. 2016, 34 (Suppl. 100), 23-29. [PubMed]

112. Carbone, L.D.; Warrington, K.J.; Barrow, K.D.; Pugazhenthi, M.; Watsky, M.A.; Somes, G.; Ingels, J.; Postlethwaite, A.E. Pamidronate infusion in patients with systemic sclerosis results in changes in blood mononuclear cell cytokine profiles. Clin. Exp. Immunol. 2006, 146, 371-380. [CrossRef] [PubMed]

113. Bank, I. The Role of gammadelta T Cells in Fibrotic Diseases. Rambam Maimonides Med. J. 2016, 7. [CrossRef]

(C) 2020 by the author. Licensee MDPI, Basel, Switzerland. This article is an open access article distributed under the terms and conditions of the Creative Commons Attribution (CC BY) license (http://creativecommons.org/licenses/by/4.0/). 